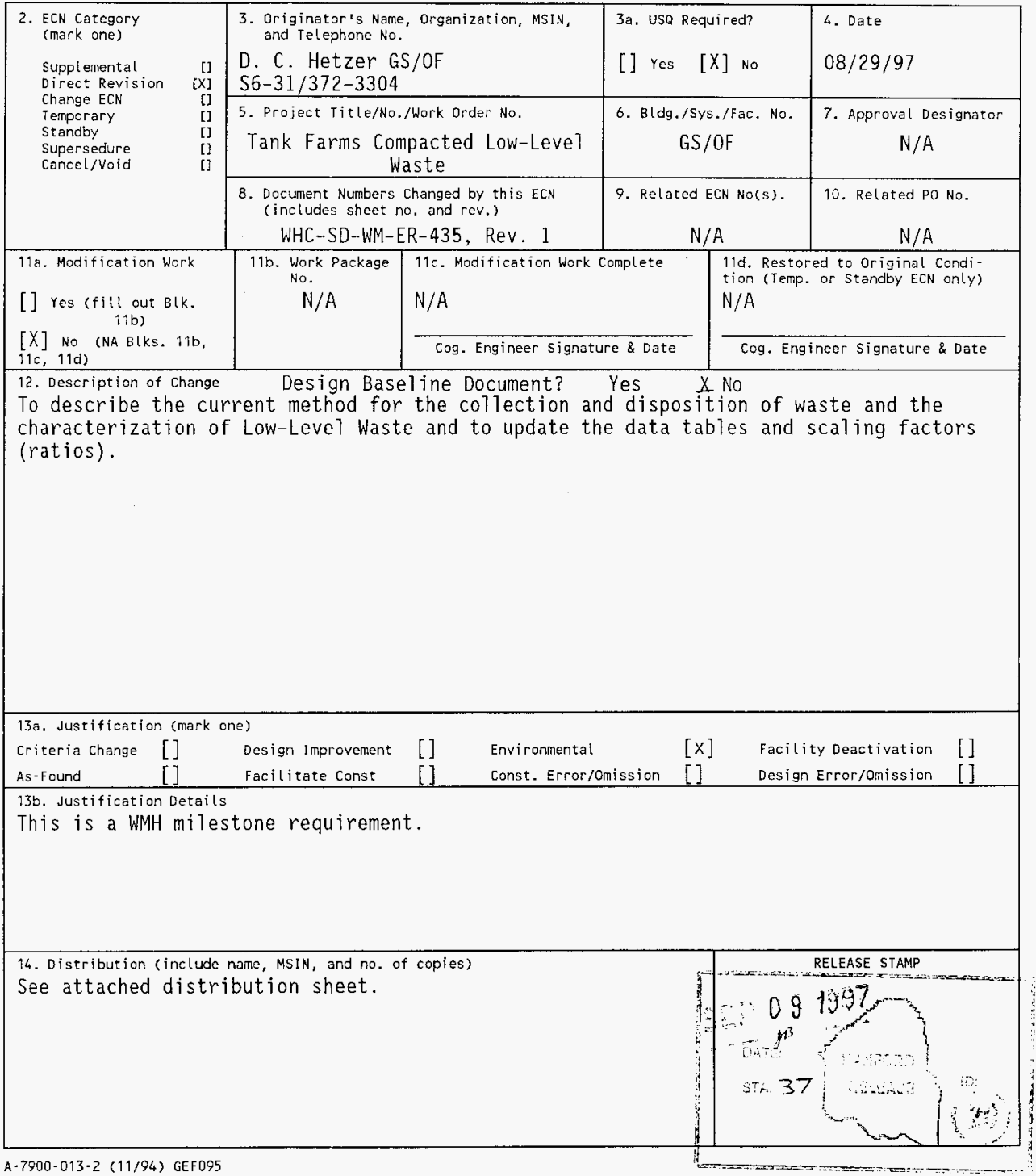




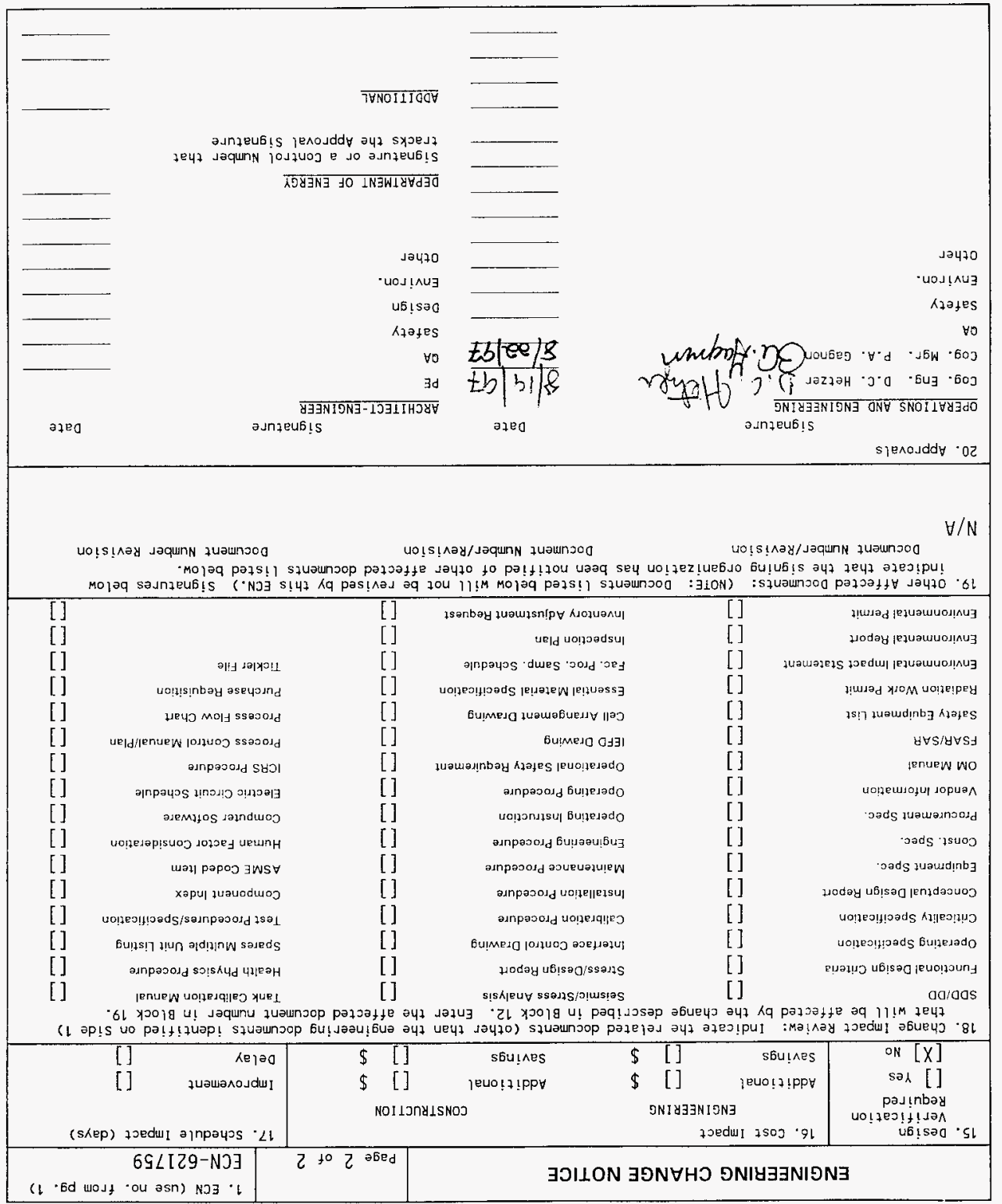




\section{Tank Farms Compacted Low-Level Waste}

D. C. Hetzer

Waste Management Federal Services of Hanford, Inc., Richland, WA 99352 U.S. Department of Energy Contract DE-AC06-96RL13200

EDT/ECN: 621759

Org Code: 33240

UC: 2070

B\&R Code: EW3130020

Charge Code: N1068

Total Pages: $-2 \frac{5-56}{z_{8}}$

Key Words: Solid Low-Level Waste, Tank Farms, LLW, Compaction, TWRS, Radionuclide Characterization

Abstract: This report describes the process of Low-Level Waste (LLW) volume reduction by compaction. Also included is the data used for characterization of LLW destined for compaction. Scaling factors (ratios) are formed based on data contained in this report.

TRADEMARK DISCLAIMER. Reference herein to any specific comercial product, process, or service by trade name, tradenark, manufacturer, or otherwise, does not necessarily constitute or imply its endorsement, recommendation, or favoring by the United states Government or any agency thereof or its contractors or subcontractors.

Printed in the United States of America. To obtain copies of this document, contact: Document Control Services, P.O. Box 950, Mailstop H6-08, Richland WA 99352, Phone (509) 372-2420; Fax (509) 376-4989.
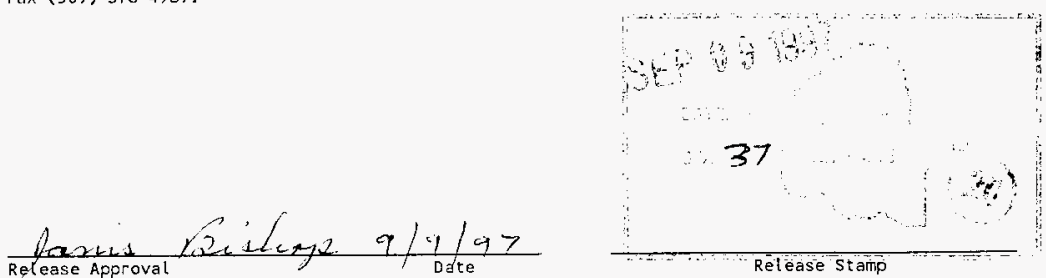

\section{Approved for Public Release}




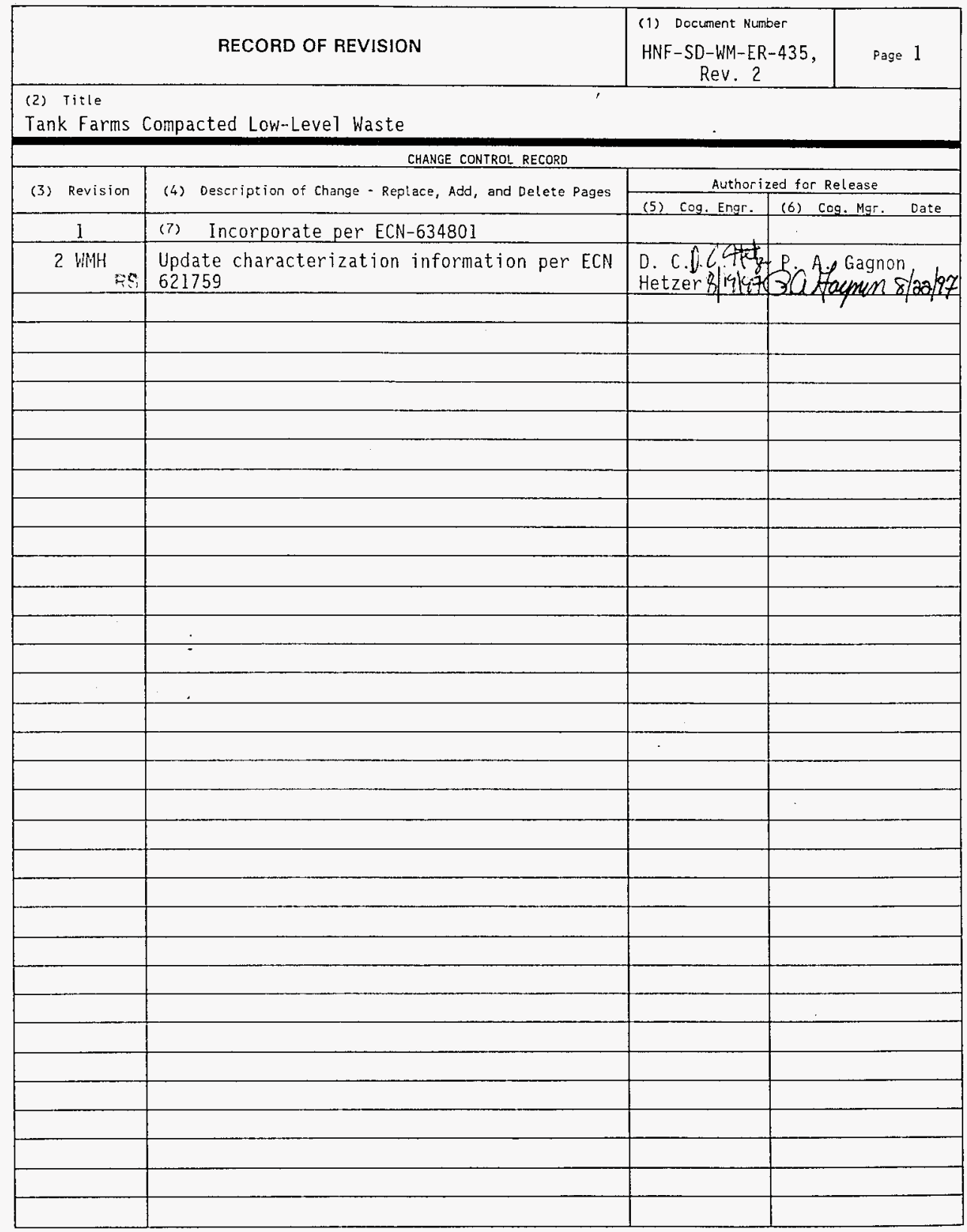


HNF-SD-WM-ER-435, Rev. 2

TANK FARMS COMPACTED LOW-LEVEL WASTE

AUGUST 1997

Prepared By:

David C. Hetzer

Prepared For

Waste Management Federal Services of Hanford, Inc. (WMH) 


\section{CONTENTS}

LIST OF TERMS $\ldots \ldots \ldots \ldots \ldots \ldots \ldots \ldots \ldots \ldots \ldots \ldots \ldots \ldots$ iv

LIST OF DEFINITIONS $\ldots \ldots \ldots \ldots \ldots \ldots \ldots \ldots \ldots \ldots$

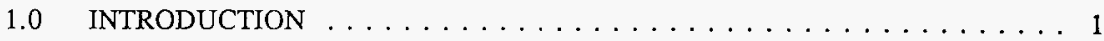

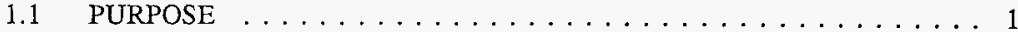

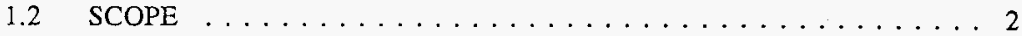

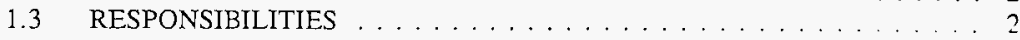

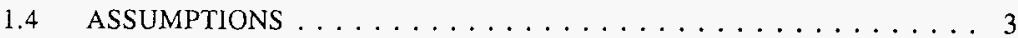

2.0 DESCRIPTION OF THE LLW WASTE STREAM $\ldots \ldots \ldots \ldots \ldots \ldots$

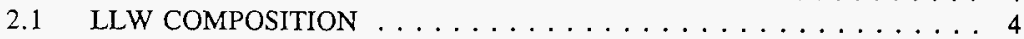

2.2 WASTE STREAM IDENTIFICATION $\ldots \ldots \ldots \ldots \ldots \ldots \ldots$

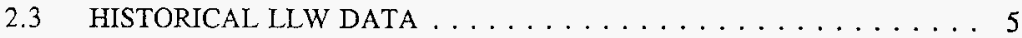

3.0 LLW SAMPLING AND ANALYSIS $\ldots \ldots \ldots \ldots \ldots \ldots \ldots \ldots$

3.1 DESTRUCTIVE SAMPLING AND ANALYSIS $\ldots \ldots \ldots \ldots \ldots \ldots 7$

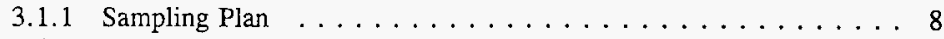

3.2 NON-DESTRUCTIVE ANALYSIS $\ldots \ldots \ldots \ldots \ldots \ldots$

3.2 .1 6-Point Survey $\ldots \ldots \ldots \ldots \ldots \ldots \ldots \ldots \ldots \ldots \ldots$

3.2 .2 PNNL Assay System $\ldots \ldots \ldots \ldots \ldots \ldots \ldots$

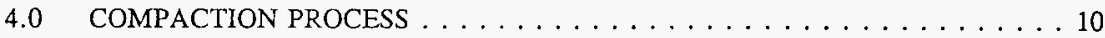

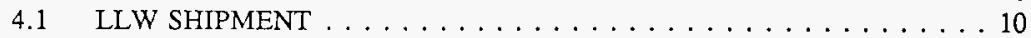

4.2 INITIAL COMPACTION $\ldots \ldots \ldots \ldots \ldots \ldots \ldots \ldots \ldots$

4.3 SUPERCOMPACTION $\ldots \ldots \ldots \ldots \ldots \ldots \ldots \ldots \ldots \ldots \ldots$

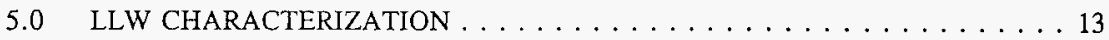

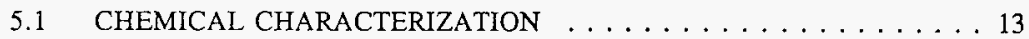

5.2 RADIOLOGICAL CHARACTERIZATION ..........13

5.2.1 RESULTS OF THE JANUARY AND MARCH SAMPLING

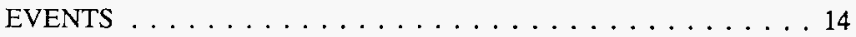

6.0 CONCLUSIONS AND RECOMMENDATIONS $\ldots \ldots \ldots \ldots \ldots \ldots$

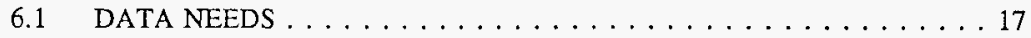

6.2 SAMPLING AND ANALYSIS $\ldots \ldots \ldots \ldots \ldots \ldots \ldots \ldots \ldots \ldots$

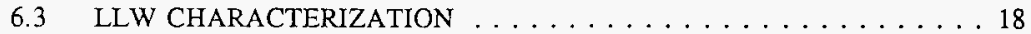

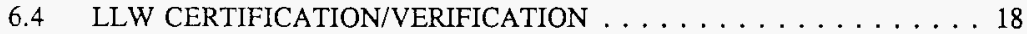

REFERENCES . . . . . . . . . . . . . . . . . . . 19 
HNF-SD-WM-ER-435, Rev. 2

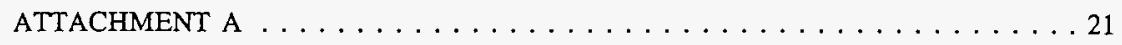

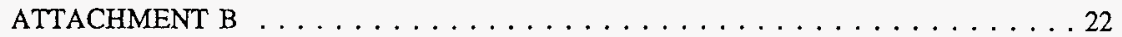

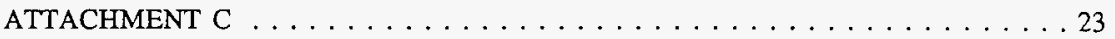

ATTACHMENT D . . . . . . . . . . . . . . . . . 24

ATTACHMENT E ....................... 25 
HNF-SD-WM-ER-435, Rev. 2

\section{LIST OF TERMS}

$\begin{array}{ll}\text { ATG } & \text { Allied Technology Group } \\ \text { DOE } & \text { Department of Energy } \\ \text { GS/O } & \text { Generator Services/Operations } \\ \text { GS/OF } & \text { Generator Services/Operating Facilities } \\ \text { FDH } & \text { Fluor Daniel Hanford, Inc. } \\ \text { LLW } & \text { Low-Level Waste } \\ \text { LMHC } & \text { Lockheed Martin Hanford Corporation } \\ \text { MW } & \text { Mixed Waste } \\ \text { NHC } & \text { Numatec Hanford Corporation } \\ \text { PIN } & \text { Package Identification Number } \\ \text { PLAN } & \text { Radionuclide Characterization Program Plan } \\ \text { PNNL } & \text { Pacific Northwest National Laboratories } \\ \text { SAS } & \text { Special Analytical Services } \\ \text { SDLA } & \text { Sample Data and Laboratory Administration } \\ \text { SML } & \text { Sampling and Mobile Laboratories } \\ \text { TRU } & \text { Transuranic } \\ \text { TS } & \text { Technical Services } \\ \text { TWRS } & \text { Tank Waste Remediation Systems } \\ \text { WMH } & \text { Waste Management Federal Services of Hanford, Inc. } \\ \text { WSCF } & \text { Waste Sampling and Characterization Facilities }\end{array}$




\section{LIST OF DEFINITIONS}

Accuracy. The closeness of agreement between an observed value and an accepted reference value.

Characterization. The determination of the waste composition and properties, whether by review of process knowledge, nondestructive examination or assay, or sampling and analysis, or a combination thereof, done for the purpose of determining appropriate storage, treatment, handling, transportation, and disposal requirements.

Curie. A quantitative measure of radioactivity equal to $3.7 \times 10^{10}$ disintegrations per second.

Data Quality Objectives (DQOs). A statement of the overall level of uncertainty that a decision-maker is willing to accept in results derived from data. This uncertainty is used to specify the quality of the measurement data required, usually in comparability; and completeness. The DQOs should be defined prior to the initiation of the field and laboratory work.

Data Validation. The process of evaluating the available data against the project DQOs to make sure that the objectives are met. The available data reviewed will include analytical results, field quality control (QA) data and lab QC data, process records and may also include field records.

Detection Limit. Lowest amount that can be distinguished from the normal random "noise" of an analytical instrument or method.

Interim Characterization. An Interim Characterization is used as a practical and temporary approach that satisfies regulatory requirements and allows for current waste issues to be dealt with until the detailed information can be acquired for a complex waste stream.

Low-Level Waste (LLW). Waste that contains radioactivity and is not classified as high-level waste, transuranic (TRU) waste, spent nuclear fuel, or byproduct material as defined by DOE Order $5820.2 \mathrm{~A}$.

Matrix. The component or substrate which contains the analyte of interest.

Mixed Waste. Waste containing both radioactive and hazardous components as defined by the Atomic Energy Act (ATEA) and the Resource Conservation and Recovery Act (RCRA), respectively. (10 CFT 20.1003)

Process Knowledge. Documented evidence of past or current industrial (including chemical) practices. 
Quality Assurance (QA). An integrated system or program of activities involving planning, quality control, quality assessment, reporting and quality improvement to ensure that a product or service meets the defined standards of quality with a stated level of confidence.

Quality Control (QA). The overall system of routine technical activities whose purpose is to measure and control the quality of a product or service so that it meets the needs of its users.

Radioactive Material. Any material having a specific activity greater that 0.002 microcuries per gram (uCi/g). (49 CFR 173.403)

Radioactive Waste. Solid, liquid, or gaseous materials, of no commercial value that emits ionizing radiation. Discarded items such as clothing, containers, equipment, rubble, residues, or soils that contain radionuclides.

Recertification of a Waste Stream. It is that aspect of a characterization program that assures the radionuclide distribution has not changed, with respect to time, for a waste stream.

Scaling Factors (Ratios). A multiplier that allows the inference of one difficult to measure radionuclide concentration from another that is more easily measured.

Segregation. The process of segregating (or keeping separate) individual waste types and/or forms in order to facilitate their cost-effective treatment and storage or disposal.

Waste Container. The waste, waste package, and any absorbent that are intended for disposal as a unit.

Waste Stream. A waste stream is any consistent set of waste material from a given process or set of closely related processes that does not change in its physical, radionuclide, or chemical designation, or in its means of packaging. Waste streams are established to meet the requirements in the Waste Specification System document, WHC-EP-0846. 


\subsection{INTRODUCTION}

Solid low-level waste (LLW) is generated during routine tasks from Lockheed Martin Hanford Corporation (LMHC) Tank Waste Remediation Systems (TWRS) programs and then shipped to the Allied Technology Group (ATG) for volume reduction utilizing super compaction. Waste Management Federal Services of Hanford, Inc. (WMH), Generator Services/Operating Facilities (GS/OF), manages, for LMHC, all containerized solid LLW generated from these activities. The solid waste is collected at various locations throughout the farms and then transported and consolidated into Sea-Land containers at the 209E Facility. Generator Services/Operations (GS/O) receives waste and then GS/OF characterizes for proper designation and then prepared for shipment to ATG and ultimately the compacted waste is sent to the burial grounds. This report presents an overview of processes that identifies LLW destined for compaction and the waste characterization effort performed by GS/OF.

There have been several changes in this process since the last revision of this document. The collection method has changed and several additional sampling events have occurred for this waste stream. These samples were analyzed using a more extensive radionuclide list and sensitive techniques. These results are included to increase the analysis data base and update scaling factors. Page change $\# 5$ of the "Hanford Site Solid Waste Acceptance Criteria" manual, WHC-EP-0063-4 was issued in May 1996. This page change has added requirements for reporting certain mobile radionuclides for waste disposal in the burial grounds.

\subsection{PURPOSE}

The purpose of this report is to provide the radionuclide data to characterize this waste stream for determining the inventory of waste containers. The process of LLW volume reduction by supercompaction and data utilization is also presented to provide a complete description of the method to ultimately determine the waste category for disposal. This report summarizes available information on identified components of the LLW waste stream, LLW historical data, sampling and analysis and LLW characterization data. Utilizing the above data, informed decisions can be made with regard to the ultimate disposition of LLW and the supercompaction process. Specific objectives of this report include;

- A description of the LLW waste stream components and an evaluation of the associated data. 
HNF-SD-WM-ER-435, Rev. 2

- A description of the supercompaction process.

- Characterization of the LLW waste stream utilizing available sampling and analysis data.

- Determine scaling factors (ratios) for LLW.

\subsection{SCOPE}

First, this report presents a description of the LLW composition and waste stream components considered for volume reduction. Next, a historical description of available LLW data is presented. This information includes data extracted from files used to ship LLW during 1993 and 1994. Next, a description of the LLW sampling and analysis followed by the process of waste preparation and supercompaction will be discussed. Finally, the characterization effort will be presented.

\subsection{RESPONSIBILITIES}

Generator Services/Operations (GS/O)

GS/O collects and manages the solid waste generated from Tank Farms. They will provide for the transportation of containers and review of the documentation before shipment to a designated storage location once the containers are full or will no longer be used. Sampling will be performed as required to characterize the waste.

Generator Services/Operating Facilities (GS/OF)

GS/OF will identify waste containers in need of sampling and analysis as well as coordinate the activities of the GS/O, SDLA, and SML so that sampling efforts proceed on a timely basis. This group will ensure that the waste characterization program is accurate and consistent leading to correct waste designations and category and shipping determinations.

Radiological Instrumentation and Application (PNNL)

Upon request by GS/OF, PNNL will perform gamma (high energy photon) and neutron assays of waste containers. 
HNF-SD-WM-ER-435, Rev. 2

Sample Data and Laboratory Administration (SDLA)

SDLA coordinates analyses of samples at on-site and off-site laboratories and is the central point of contact for the laboratories. SDLA validates and verifies analytical data received from the laboratories. SDLA maintains the original hard copy laboratory data and meets the requirements in the Data Management section of the radionuclide characterization plan described in the HNF-SD-WM-PLN-115, Rev. 1, document.

Sampling and Mobile Laboratories (SML)

Upon request by Generator Services/Operating Facilities (GS/OF), SML will take samples for shipment, maintain a field logbook, prepare chain-of-custody records, and ship the samples to the designated laboratories.

Technical Services (TS)

Technical Services (TS) will review and approve waste portfolios submitted by GS/OF.

\subsection{ASSUMPTIONS}

The processes described in this report are based on current operating procedures and regulations with regards to the handling of LLW. LLW waste stream component identification and the composition of LLW is subject to change as the scope of work changes within Tank Farms.

This report will be reviewed annually, at a minimum, to evaluate its validity and will be revised as necessary. 
HNF-SD-WM-ER-435, Rev. 2

\subsection{DESCRIPTION OF THE LLW WASTE STREAM}

The purpose of this section is to provide an overview of the LLW waste stream and methods regarding the handling and disposition of identified LLW. This section will cover the composition of $\mathrm{LLW}$, identification of the waste stream components and historical LLW data.

\subsection{LLW COMPOSITION}

Tank Farms LLW consists mostly of debris generated as a result of activities conducted within tank farms themselves. These activities include but are not limited to routine surveillance and maintenance, construction, demolition, facility upgrades, and general cleanup of tank farms. This debris is contaminated with radioactive isotopes mainly due to tank farm general area contamination. This debris has not come into contact with tank waste or chemical products regulated as dangerous waste (Ref. 4). At the current time, LLW dose rates are generally limited to $<10 \mathrm{mr} / \mathrm{hr}$ (Ref. 5).

The debris that makes up a majority of the accumulated LLW is cloth, rubber, paper, plastic, wood, concrete, and metal.

\subsection{WASTE STREAM IDENTIFICATION}

In the past there have been as many as seventeen (17) components identified for the LLW waste stream. This still holds true. There are times when a waste stream component may become inactive and not produce LLW on a routine basis. There are various reasons that identified waste stream components may change or become inactive. As tank farms are declared clean and stable there is very little, if any, LLW generated at that point. The installation of remote surveillance equipment in tank farms requires fewer personnel entries thus reducing the amount of waste generated. Although these waste stream components may become inactive they are still monitored by GS/O for collection of LLW. Table 2-1 illustrates the division of three (3) separate areas which are 200 East Tank Farms, 200 East Miscellaneous Areas, and 200 West Tank Farms. Subsequently each of these areas is broken down into locations of the collection point and then indicates which areas are serviced by each collection point.

There are instances when LLW containers will be issued for a particular work function to be conducted within tank farms. This may include removal of large equipment or materials or large scale farms cleanup where substantial quantities of LLW is expected to be generated. These container locations are tracked by GS/O. 
HNF-SD-WM-ER-435, Rev. 2

A Sea-Land conex is maintained at the 209-E facility by GS/O. This is used for interim storage and as a shipping container for LLW that is destined for compaction. Routine pickup of the LLW waste from the collection points throughout Tank Farms is then returned to the 209-E Sea-Land container. This will be discussed further in Section 4.

\subsection{HISTORICAL LLW DATA}

A review of the files for previously generated LLW during the periods of 1993 to 1994 was conducted. The Package Identification Number files, or PIN files, contain information utilized for shipment of a LLW waste container. Pertinent information within these files could be used to aid in developing a history of the LLW waste stream and thus serve as documented process knowledge. Information collected was the PIN number for tracking purposes, the collection point and point of waste origin, weight and volume of the waste, the results of the 6-point radiation survey, results of the Pacific Northwest National Laboratory (PNNL) Assay and sample results if either were conducted, and the contents of the container as indicated on the inventory sheets. This information or data is summarized in Attachment A. 
HNF-SD-WM-ER-435, Rev. 2

Table 2-1

COMPONENTS OF THE LOW-LEVEL WASTE STREAM

\begin{tabular}{|c|c|}
\hline Location of Collection Point & Areas Serviced \\
\hline \multicolumn{2}{|l|}{200 East Tank Farms } \\
\hline 241-AN & 241-AN \\
\hline 241-AP & 241-AP \\
\hline 241-AW & 241-AW \\
\hline 241-AY & 241-AX, AY, AZ \\
\hline 241-B & 241-B, 242-B, 242-BL \\
\hline 241-BX & 241-BX, BY, BXR \\
\hline $241-\mathrm{C}$ & $\begin{array}{l}\text { 241-C, 244-CR, } \\
271-\mathrm{CR}\end{array}$ \\
\hline \multicolumn{2}{|l|}{200 East Miscellaneous } \\
\hline 242-A, EVAPORATOR & $242-\mathrm{A}$ \\
\hline $\begin{array}{l}\text { 204-AR, RAILCAR } \\
\text { UNLOADING FACILITY }\end{array}$ & 204-AR \\
\hline $\begin{array}{l}\text { 209-E, ENVIRONMENTAL } \\
\text { WASTE OPERATIONS }\end{array}$ & 209-E, REPACKAGING \\
\hline 244-A, LIFT STATION & $244-\mathrm{A}$ \\
\hline \multicolumn{2}{|l|}{200 West Tank Farms } \\
\hline $241-S$ & $241-S, S X$ \\
\hline 241-SY & 241-SY \\
\hline $241-\mathrm{T}$ & $241-T$ \\
\hline 241-TX & 241-TX, TY \\
\hline $241-U$ & $241-\mathrm{U}$ \\
\hline
\end{tabular}




\subsection{LLW SAMPLING AND ANALYSIS}

The purpose of this section is to provide an overview of sampling and analysis associated with LLW. Sampling and analysis is conducted to determine the identity and quantity of radionuclides present in LLW. This section will address destructive and non-destructive analysis.

\subsection{DESTRUCTIVE SAMPLING AND ANALYSIS}

Destructive sampling is performed by physically removing a portion of the waste for analysis. The sample is then placed into a container and transported to a laboratory for analysis. The sample matrix is selected which best represents the majority of the waste matrix from that particular waste stream component. The samples are collected in the field by GS/O at each identified LLW waste stream component location. As discussed earlier in this report, the majority of the waste matrix to be sent for compaction is paper, cloth, rubber, and plastic. Small pieces of wood, concrete, and metal may also be included in compactable waste containers.

Typical analyses requested on LLW are Total Alpha (TA), Total Beta (TB), and Gamma Energy Analysis (GEA) although additional analyses may be requested. In order to perform the requested analyses on samples of this matrix, the laboratory will pretreat and prepare the sample using various laboratory techniques. After the requested analyses have been performed, the sample may then be archived at the laboratory for a period of time. If after review of the analysis results it is determined that additional analyses are required, the lab can be notified and the analysis completed on the remaining portion of the sample. If the results of the analyses are acceptable, the sample may then be discarded.

From a review of the historical data of LLW from within Tank Farms (Attachment A) it was evident that there was insufficient data to make informative decisions about the characterization of LLW destined for compaction. It was therefore decided to establish a plan to perform sampling and analysis of the waste stream components identified in Table 2-1. The results of these sampling and analysis efforts will establish a database to formulate characterization of the waste stream components. 


\subsubsection{Sampling Plan}

For this document, a sampling plan was developed to identify radionuclides generated from the waste stream components identified in Table 2-1. The plan specified that two separate sampling periods would be conducted. PNNL was contacted and they supplied sampling containers that had tare weight determined. This step would allow for the results to be reported in the units of $\rho \mathrm{Ci} / \mathrm{g}$. The first set of samples were collected in January 1996 and the second set was collected in March 1996. There were also blank samples sent to the lab to verify no cross-contamination was occurring. The blank samples indicated that no cross-contamination was occurring during laboratory analysis. This data is maintained in accordance with the GS/OF Data Management Plan.

There were several reasons for having the samples analyzed at a PNNL facility rather than the onsite facility that had been used in the past. The initial issue of this document and the "Tank Farms Radionuclide Characterization Program Plan", HNFSD-WM-PLN-115, recommended the procurement of a laboratory facility that had the capabilities to perform analyses on samples utilizing an extended radionuclide list, meet our required sensitivities, and do so in a cost effective manner. Also a contributing factor to this endeavor was page change \#5 to "Hanford Site Solid Waste Acceptance Criteria", WHC-EP-0063-4. This page change included the requirements for reporting certain mobile radionuclide concentrations for waste disposed in burial grounds. The onsite laboratory facility does not have the capability to meet TS needs for these radionuclides. Results of the two sets of samples collected are tabulated in Tables 1 and 2 of Attachment B.

\subsection{NON-DESTRUCTIVE ANALYSIS}

\subsubsection{6-Point Survey}

The 6-point survey is routinely conducted on all LLW containers. This involves a radiation survey meter to take contact radiation measurements on each side of the container. The dose rate measurements are recorded on a survey sheet. The results of the 6-point survey can be utilized to determine Cs-137 content of the container by using curves presented in the WHC-SD-WM-PROC-020 document. However, in order to consider the dose-rate to curie curves valid, two things should be known. First, it should be established that the predominant gamma emitting isotope of the waste is Cs-137. Secondly, the inventory of the container will be used to determine an approximate waste matrix density so that the appropriate dose-rate to curie curve can be utilized. The Cs- 137 value determined by this method can then be used for characterization. 
HNF-SD-WM-ER-435, Rev. 2

\subsubsection{PNNL Assay System}

The PNNL Assay System consists of gamma sensitive detectors and supporting computer equipment to identify and quantify the major gamma-emitting isotopes within the waste container. There are separate systems used for LLW boxes and LLW drums. The PNNL Assay System also contains a passive-neutron system for the determination of TRU content of a waste container. The system has the advantage of being mobile which allows waste to be assayed prior to it being shipped from the Hanford Site and later at the compaction site after the initial compaction process. This is useful for verification and comparison purposes. The PNNL Assay Systems are operated in accordance with approved PNNL procedures. (Ref. 7, 8) 
HNF-SD-WM-ER-435, Rev. 2

\subsection{COMPACTION PROCESS}

The purpose of this section is to provide an overview of the LLW compaction process. This section will address the current practice for shipment of LLW for compaction and an overview of the compaction process. An illustration of the compaction process is included as Figure 4-1.

\subsection{LLW SHIPMENT}

Prior to November 1995, tank farms LLW destined for compaction was packaged in the field in plastic bags and stored at one of the accumulation points until picked up by GS/O personnel. The waste was then transported to the 209-E facility and accumulated in a waste container. The waste containers maintained at the 209-E facility were $4^{\prime} \times 4^{\prime} \times 8^{\prime}$ (or similar size) boxes that mimicked the accumulation areas identified in Table 2-1. Noncompactable waste is still segregated and placed in a separate container. When the containers were full they were prepared for shipment to the ATG compaction facility for volume reduction. The boxes were weighed to determine waste weight and an assay was performed by PNNL for characterization purposes.

In November 1995, EWO placed the Sea-Land containers into service on the LLW Pad at the 209-E Facility. The Sea-Land container is $8^{\prime} \times 8^{\prime} \times 20^{\prime}$ and is used for intermediate storage and shipment of LLW to ATG. "Operate the Low-Level Waste Pad", TO-100-056, is the procedure that directs operation of the low level waste pad. When the waste is returned to the 209-E facility, it is recorded on the "Farm Specific Log Sheet". Every tenth bag for that specific farm is placed in a "Sample LLW Box". If a waste bag is not to be placed in the "Sample LLW Box" it is placed in the Sea-Land container. When the Sea-Land container is full, the "Sample LLW Box" activity is measured and the results used for characterization of the Sea-Land container. Transportation vehicles for shipment of the LLW containers is supplied by ATG.

\subsection{INITIAL COMPACTION}

When the waste shipment has been accepted at ATG, the bags of waste are removed from the container and prepared for compaction. At the first compaction process the bags are compacted into DOT $17 \mathrm{H}$ or UN1A2 painted steel 55 gallon drums. ATG is provided with instructions that specifies waste shall not be commingled. In other words, tank farms LLW will not be mixed with waste from another source during the compaction process. 
Initially the wooden boxes that were used for the LLW shipments to ATG were dismantled and compacted along with the waste that they contained. After the first two shipments it was determined that the boxes would be surveyed and reused when possible. This would improve the compaction ratios to the desired levels. With the use of the Sea-Land containers, the only wooden boxes used are for the "Sample LLW Box". When enough of the "Sample LLW Boxes" are amassed, they are shipped to ATG. The empty boxes are then returned to 209-E for reuse unless they are damaged at which point ATG would not return the box.

\subsection{SUPERCOMPACTION}

After the initial compaction of the waste into the 55 gallon drums, these drums then undergo supercompaction. This process results in the drums being reduced to "pucks" of varying dimensions. These "pucks" are then placed into larger overpacks meeting either DOT 7A Type A, UN1A2, or strong tight container specifications. These overpacks range in size from 64 to 85 gallons. ATG is then responsible for preparation of the shipping papers and return of the compacted waste to the Hanford Site. 
HNF-SD-WM-ER-435, Rev. 2

Figure 4-1

\section{LLW VOLUME REDUCTION}

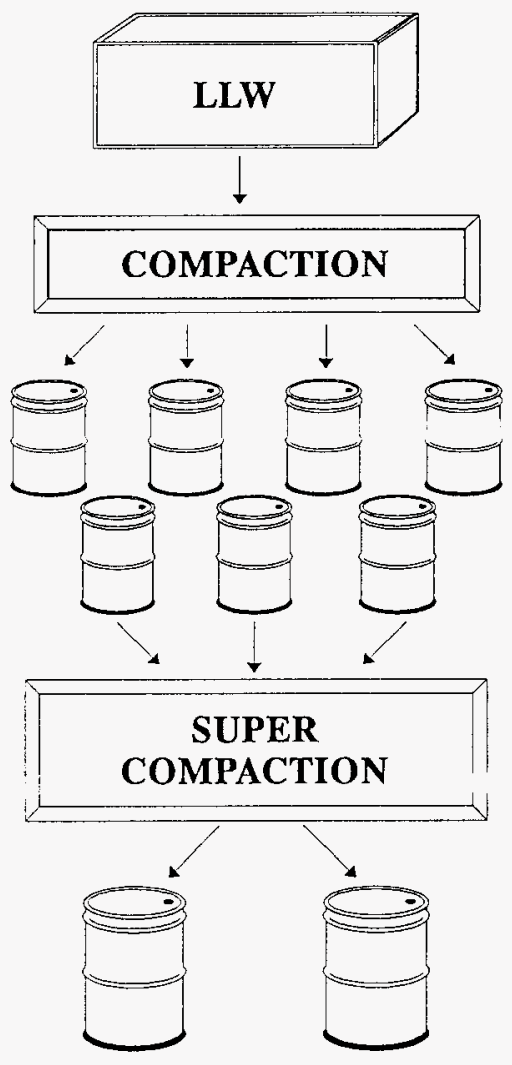




\subsection{LLW CHARACTERIZATTON}

The purpose of this section is to provide an overview of the Characterization process for LLW destined for volume reduction.

\subsection{CHEMICAL CHARACTERIZATION}

Debris from tank farms is considered mixed waste if it contains tank waste. By definition, LLW waste is that fraction of waste generated throughout tank farms which does not contain tank waste (Reference 18). Chemical products from various activities within tank farms may be present is LLW destined for compaction. Only nonregulated products, regulated products at concentrations below the regulatory limits, or empty containers of regulated products would be found in LIW.

\subsection{RADIOLOGICAL CHARACTERIZATION}

The radionuclide concentrations of LLW originates from the general area surface contamination from within tank farms. Debris is generated from various activities within tank farms such as maintenance and surveillance monitoring. Materials from this waste stream are segregated from mixed waste, i.e. tank contacted waste per procedure T0-100-052 (Reference 13). A review of the data indicates that the major radionuclide constituents are CO-60, SI-90/Y-90, Cs-137/Ba-137m and $\mathrm{P}_{\mathrm{U}-241}$ with limited quantities of alpha emitting radionuclides.

Characterization of the LLW waste stream components has relied on a combination of non-destructive and destructive analysis combined with a review of historical data. With the completion of two destructive sampling and analysis events, an overall composition of the LLW waste stream components could be formulated. These sampling events were conducted over a time period of approximately four months. A review of the data indicates that the composition of the LLW waste stream components is fairly consistent. This data identifies Cs-137 as the primary gamma emitting radionuclide. With this being the case, scaling factors (ratios) are developed that will be utilized with a non-destructive assay method for characterization purposes and to determine waste category.

ATG is responsible for category determination of the compacted LLW. that is returned to the Hanford Site. ATG, through their internal tracking system will determine the category of the compacted LLW based on the information supplied to them by the shipping organization. During the supercompaction process the compacted waste may occasionally reach Category 3 limits. Category 3 supercompacted LLW will be managed under its own Waste Specification Record. 


\subsubsection{RESULTS OF THE JANUARY AND MARCH SAMPLING EVENTS}

This section provides the data to determine the radionuclide inventory of Sea-Land waste containers by two different approaches. The information given in Table 1 of Attachment $C$ provides for a concentration approach while Table 2 of Attachment $C$ uses a ratio approach to determine the radionuclide inventory for waste disposal.

The data provided in Table 1 and 2 of Attachment B were extracted from the Pacific Northwest Laboratory (PNNL), References 1, 8, 9 and 11 of this document, reports and represents the collective effort of the January 30 and March 13, 1996 sampling efforts. Pieces of gloves and rubber boots were taken from the change out trailers located in the areas described in Table 1 and 2 of Attachment B and sent to PNNL for analysis. The glove and boot samples were selected because they contain contamination indicative of the general farm environment and waste accumulated in the satellite boxes destined for the Sea-Land containers.

The data presented in Table 1 and 2 of Attachment B represents those samples that have positive nuclide results. If a radionuclide did not have a positive result for any sample location, those nuclides were not reported in the tables. PNNL did not report positive results for the following nuclides:

$\begin{array}{llll}\text { H-3 } & \text { Tc-99 } & \text { Ce-144 } & \text { U-236 } \\ \text { C-14 } & \text { Rh-106 } & \text { Bi-214 } & \text { Pu-236 } \\ \text { Mn-54 } & \text { Pd-107 } & \text { Th-228 } & \text { Pu-242 } \\ \text { Ni-59 } & \text { Ag-108m } & \text { Th-230 } & \text { Am-242m } \\ \text { Ni-63 } & \text { Sb-125 } & \text { U-232 } & \text { Am-243 } \\ \text { Se-79 } & \text { I-129 } & \text { U-233 } & \text { Cm-242 } \\ \text { Nb-94 } & \text { Cs-134 } & \text { U-234 } & \text { Cm-243/244 }\end{array}$

All the results for the nuclides listed above were below the detection limit of their respective PNNL analysis method. If a positive nuclide result occurred for only one sample location, it was reported and a zero value was used for the other locations. A value of zero was used to represent a below detection limit result and as an aid to accommodate the overall averaging of data. All of the mobile radionuclides were evaluated, except for $\mathrm{Cl}-36$, and were determined to be below analysis method detection limits except for total uranium, Np-237 and Re-187. Cl-36 was not evaluated because its presence is not predicted to be of any sufficient quantity (see Reference 6 for further explanation) in spent Hanford reactor fuel and cladding materials. The total uranium, Np-137 and Re-187 results are presented in the tables. A wide variety of radionuclides were evaluated that covered the predicted activity spectrum in LLW that originated from the Tank Farms. 
The data in Tables 1 and 2 of Attachment $C$ are the average concentrations and ratios using the combined data from Tables 1 and 2 of Attachment B. Tables 1 and 2 of Attachment $\mathrm{C}$ are the tables to use when performing a radionuclide inventory of a waste container. When the net weight and volume is the only information available for a container, the data in Table 1 of Attachment $\mathrm{C}$ can be used to determine the total activity. When nondestructive assay data is available, the ratios provided in Table 2 of Attachment $C$ can then be used to determine the activity of the more difficult to measure radionuclides. Because Cs-137 was used to develop the ratios in Table 2 of Attachment $\mathrm{C}$, an appropriate nondestructive technique must be selected that measures for Cs-137.

Tables 1 and 2 of Attachment $D$ and Tables 1 and 2 of Attachment E were developed to evaluate the potential impact of the two inventory methods with respect to Category 1, Mobile Radionuclides and TRU determinations for an average waste container situation. The average data provided in Tables 1 and 2 of Attachment $C$ and Tables 1 and 2 of Attachment D were used to generate Tables 1 and 2 of Attachment $E$. Tables 1 and 2 of Attachment $E$ provide the information to evaluate the concentration and ratio approaches, respectively. The Category 1 and the Mobile Radionuclide Reporting limits were obtained from the WHC-EP-0063-4 (page change \#5) manual.

The information provided in Tables 1 and 2 of Attachment $E$ shows that the concentration and ratio approaches will produce results that do not exceed the Category 1, Mobile Reporting and TRU limits. The total uranium concentration for compacted waste produces the greatest impact upon the Mobile Radionuclide Reporting requirement. The recent PNNL data was selected to replace the past data, presented in the WHC-SD-WM-ER-435, Rev. 1, document, because of its present applicability, consistency and in-depth analysis especially with respect to the mobile radionuclides. It is interesting to note that the identified mobile radionuclides have naturally occurring in addition to artificially produced origins. Because the data given in Tables 1 and 2 of Attachment B are at environmental levels, it is quite possible that the mobile radionuclides have a naturally occurring origin.

The U-isotopic and Total-U data provided in Tables 1 and 2 of Attachment $\mathrm{C}$ are corrected data from the original sample data provided in the "Compacted Low-Level Waste Characterization Report, "Internal Memo 77520-96-050, October 9, 1996. The corrected U-234 and U-235 isotopic and Total-U data is based upon the original average U-238 pCi/g sampling result, Table 3 of the 77520-96-050 Internal Memo, and the $U$ isotopic distribution determined from the average 200 Area soil data presented in Table E-2 of the "Westinghouse Hanford Company Operational Environmental Monitoring Annual Report, CY 1993", WHC-EP-0573-2. Given below is the average $U$ isotopic data determined from the WHC-EP-0573-2 report: 


$\begin{array}{lccc}\text { NUCLIDE } & \text { Average pCi/g } & \text { \% Activity Distribution } & \text { \% Mass Distribution } \\ \text { U-234 } & 1.70 \mathrm{E}-1 & 47.8 & 5.10 \mathrm{E}-3 \\ \text { U-235 } & 7.40 \mathrm{E}-3 & 2.1 & 6.41 \mathrm{E}-1 \\ \text { U-238 } & 1.78 \mathrm{E}-1 & 50.1 & 9.93 \mathrm{E}+1\end{array}$

Because the original ORIGIN 2 computer runs did not account for the U-234 that was present before reactor operation, the total $U$ activity was not adequately accounted for in the initial 77520-96-050 Internal Memo report. The U isotopic distribution presented above is appropriate for the compacted waste stream. The U-234, 235 and 238 isotopic distribution is based upon actual data that represents the general source of contamination for the low-level compacted waste. J. W. Schmidt, author of the WHC-EP-0573-2 report, told me that Quanterra, Inc. (The analytical laboratory that analyzed the soil samples for their $U$ isotopic content by an alpha spectrometry method.) only observed the U-234, 235 and 238 isotopes. Further study will be required when establishing the U-233, 234, 235, 236, and 238 distributions for items that comes in contact with tank waste.

The data provided in Table 2 of Attachment D came from the "Low-Level Waste-1996 PNNL Assay Results Report." This report provides results that represent all LLW that was sent to the burial grounds from TWRS. The ratios provided in Table 2 of Attachment $D$ demontrate that the ratios provided in Tables 1 and 2 of Attachment $\mathrm{C}$ will yield greater nuclide concentrations and thus be conservative when determining the waste category and reviewing the mobile radionuclide trigger levels in the WHC-EP-0063 manual. 
HNF-SD-WM-ER-435, Rev. 2

\subsection{CONCLUSIONS AND RECOMMENDATIONS}

\subsection{DATA NEEDS}

The data and information gathered to support this document was done so to supply information particular to the LLW that is destined for compaction. A detailed evaluation was conducted and ratios determined. A continuing effort should be made to included information that would support accurate characterization of the LLW for compaction. Data will be organized and maintained in accordance with WHC-SD-WM-PLN-100, Waste Shipment Engineering Data Management Plan, (Reference 17).

\subsection{SAMPLING AND ANALYSIS}

The sample results of the LLW waste stream components indicate the presence of Co-60 in a large majority of the samples. Although Cs-137 is clearly the predominant gamma emitter, the fact that Co-60 is present should be evaluated. This is of particular concern when applying the current Dose-Rate-to-Curie curves for category determination. These curves only consider Cs-137 as the source. If Cs-137 represents $95 \%$ of the activity, the change to the Dose-Rate-to-Curie curves will be negligible due to the presence of other gamma emitters. If $\mathrm{Co}-60$ and other gammaray emitters are present and contribute greater than $5 \%$ of the total gamma activity, new curves should be developed to reduce the overestimation of the radionuclide content. Co-60 should also be evaluated for potential alternative uses in the absence of Cs-137.

The current method for determining the Cs-137 activity and the application of scaling factors should be continued. This method uses the "Sample LLW Box" in conjunction with the PNNL assay system to determine the Cs-137 activity as well as activity for other gamma-ray emitting radionuclides, i.e., Co-60, Eu-152, Eu-154, and Eu-155. Scaling factors should not be used for the "other" gamma-ray emitters due to the fact that the PNNL assayer will identify them if present. The Dose-Rateto-Curie curves can be used with a micro Rem/hr meter for very low activity containers to provide results below the Total- $U$ trigger value in Table 3-2 of WHC-EP-0063-4.

Results of the Uranium analyses conducted on the LLW samples indicate the presence of Uranium in all of the samples submitted. With the implementation of page change \#5 of WHC-EP-0063-4, specifically Table 3-2 reporting requirements, Uranium concentrations could be of concern at some point in time. Page change \#5 of WHC-EP-0063-4 specifies that "if the waste contains radionuclide concentrations that are derived from both the naturally occurring radioactivity in the media and manmade contaminants, the fraction derived from the naturally occurring source can be 
HNF-SD-WM-ER-435, Rev. 2

subtracted from the total inventory or concentration for comparison to the reporting limits". There have been extensive studies and evaluations performed on the environs of surrounding areas outside of tank farms. These evaluations have indicated the presence of natural levels of Uranium. Further research should be conducted to determine if in fact the concentrations of naturally occurring Uranium can be subtracted from the Uranium concentrations found in the LLW waste stream.

\subsection{LLW CHARACTERIZATION}

Each individual LLW waste stream component should continue to be monitored to ensure that it is acceptable to consolidate the waste. Waste streams that indicate they are not compatible with others may have to be isolated and maintained as a separate waste stream. As additional data becomes available, this document will be revised with the updated information.

\subsection{LLW CERTIFICATION/VERIFICATION}

Each LLW waste stream component should be monitored to ensure that the radionuclide content is not altered. Facility changes, process changes, or changes to the major matrix contributors of compactable LLW may indicate that scaling factors need to be verified and updated. At a minimum, reverification of the radionuclide content and scaling factor values should be conducted yearly. 


\section{REFERENCES}

(1) "Additional Radiochemical Analysis Results on WSE Samples, Batches 3 and 4," Fadeff, S.K., Battelle Pacific Northwest National Laboratory, June 21, 1996.

(2) "Compacted Low-Level Waste Characterization Report, " Internal Memo 77520-96050, Hetzer, D. C., October 9, 1996.

(3) DOE Order 5820.2A, Radioactive Waste Management.

(4) DRM-001, Operation of the PNL Barrel Assay System to Measure Radioactive Emissions from 208-L Drums and Similar Containers.

(5) "Hanford Site Solid Waste Acceptance Criteria," WHC-EP-0063-4 (Page Change \#5), Willis, N.P., Westinghouse Hanford Company, May 1996.

(6) HNF-SD-WM-TI-740, Rev. O, Best-Basis Inventories for the Chemical and Radioactive Components in the Hanford Waste Tanks, to be released in August 1997.

(7) HNF-SD-WM-PLN-115, Rev 1, Tank Farms Engineering Radionuclide Characterization Program Plan.

(8) "Radiochemical Analysis on WSE Samples," Fadeff, S.K., Battelie Pacific Northwest National Laboratory, May 7, 1996.

(9) "Radiochemical Analysis Results on WSE Samples, Batches 3 and 4," Fadell, S.K., Battelle Pacific Northwest National Laboratory, June 14, 1996.

(10) "Tank Farms Compacted Low-Level Waste," WHC-SD-WM-ER-435, Rev. 1, Waters, M.S., Westinghouse Hanford Company, June 1996.

(11) "Technetium-99 Analytical Results on WSE Batch 1/2 and 3/4," Fadeff, S.K., Battelle Pacific Northwest National Laboratory, July 2, 1996.

(12) TO-100-010, Inspect, Load, and Ship Radioactive Waste To The Intermediate Holding Area.

(13) TO-100-052, Perform Waste Generation, Segregation, and Accumulation.

(14) TO-100-056, Rev. BO, Operate The Low-Level Waste Pad. 
(15) SGS-002, Burial Box Assay by High-Resolution Gamma-Ray Spectrometry and/or Neutron Counting.

(16) "Westinghouse Hanford Company Operational Environmental Monitoring Annual Report," CY 1993, WHC-EP-0573-2, 1994.

(17) WHC-SD-WM-PLN-100, Waste Shipment Engineering Data Management Plan.

(18) WSRd Number 102-02, Waste Certification Summary, Supercompacted Low-Level Waste Debris.

(19) WHC-SD-WM-PROC-020, Rev. 0, Procedure for Categorizing and Inventorying Waste in Standard Containers, by S.R. Gedeon, October 1996.

(20) WHC-SD-WM-RPT-267, Rev. 0, Basis for Dose Rate to Curie Assay Method, by S. R. Gedeon, October 1996. 
HNF-SD-WM-ER-435, Rev. 2

\section{ATTACHMENT A}


TANK FARMS LLW

93/94 HISTORICAL PIN FILES

\begin{tabular}{|c|c|c|c|c|c|c|c|c|}
\hline PIN \# & Accum. $\mathrm{Pt}$ & $\begin{array}{l}\text { Point of } \\
\text { Origin }\end{array}$ & Weight & Volume & $6 \mathrm{pt}$ & ASSAY & SAMPLE & MAJOR CONTENTS \\
\hline & & & $(\mathrm{Kg})$ & $\left(m^{3}\right)$ & $(\mathrm{mr} / \mathrm{hr})$ & $\begin{array}{c}\mathrm{Cs}-137 \underset{(\mathrm{pCi} / \mathrm{g})}{\mathrm{Co}-60}\end{array}$ & $\begin{array}{l}\text { Tot. Act. } \\
\text { (pCi/g) }\end{array}$ & (see below) \\
\hline $93-106-04$ & AN & AN & 282 & 4.0 & $<0.5$ & & & $1,2,3,4$ \\
\hline $93-106-04$ & AN & AN & 388 & 4.0 & $<0.2$ & & & $1,3,4,5,6$ \\
\hline $94-143-02$ & AN & AN & 369 & 4.0 & $<0.5$ & & & $1,2,3,4,5$ \\
\hline
\end{tabular}


TANK FARMS LLW

93/94 HISTORICAL PIN FILES

\begin{tabular}{|c|c|c|c|c|c|c|c|c|c|}
\hline PIN \# & Accum. $\mathrm{Pt}$ & $\begin{array}{c}\text { Point of } \\
\text { Origin }\end{array}$ & Weight & Volume & $6 \mathrm{pt}$ & \multicolumn{2}{|c|}{ ASSAY } & SAMPLE & MAJOR CONTENTS \\
\hline & & & $(\mathrm{Kg})$ & $\left(m^{3}\right)$ & $(\mathrm{mr} / \mathrm{hr})$ & Cs-137 & g) & $\begin{array}{l}\text { Tot. Act. } \\
\text { (pCi/g) }\end{array}$ & (see below) \\
\hline $93-105-09$ & AP & $\mathrm{AP}$ & 296 & 4.0 & $<0.5$ & & & & $1,2,3,4,5,9$ \\
\hline $93-105-10$ & AP & AP & 396.9 & 4.0 & $<0.5$ & $<0.67$ & 0.70 & & $1,2,3,4,5$ \\
\hline
\end{tabular}




\section{ATTACHMENT A}

HNF-SD-WM-ER-435, Rev. 2

Page A-3 of A-21

TANK FARMS LLW

93/94 HISTORICAL PIN FILES

\begin{tabular}{|c|c|c|c|c|c|c|c|c|c|}
\hline \multirow[t]{2}{*}{ PIN \# } & \multirow[t]{2}{*}{ Accum. Pt } & \multirow[t]{2}{*}{$\begin{array}{c}\text { Point of } \\
\text { Origin }\end{array}$} & \multirow{2}{*}{$\frac{\text { Weight }}{(\mathrm{Kg})}$} & \multirow{2}{*}{$\begin{array}{l}\text { Volume. } \\
\frac{\left(\mathrm{m}^{3}\right)}{}\end{array}$} & \multirow{2}{*}{$\frac{6 \mathrm{pt} .}{(\mathrm{mr} / \mathrm{hr})}$} & \multicolumn{2}{|c|}{ ASSAY } & \multirow{2}{*}{$\begin{array}{l}\text { SAMPLE } \\
\begin{array}{c}\text { Tot. Act. } \\
\text { (pCi/g) }\end{array}\end{array}$} & \multirow{2}{*}{$\frac{\text { MAJOR CONTENTS }}{\text { (see below) }}$} \\
\hline & & & & & & Cs-137 & Co-60 & & \\
\hline $93-105-18$ & AW & AW & 153 & 4.0 & $<0.2$ & & & & $1,2,3,4,7,8$ \\
\hline $93-105-19$ & AW & AW & 279 & 4.0 & $<0.5$ & 75.0 & 2.60 & & $2,3,4,5$ \\
\hline $93-215-03$ & AW & AW & 323 & 4.0 & $<0.5$ & & & & $1,2,3,4$ \\
\hline $94-208-02$ & AW & $\mathrm{AW}$ & 396 & 4.0 & 0.5 & & & & $1,2,3,4,5,6$ \\
\hline
\end{tabular}


TANK FARMS LLW

93/94 HISTORICAL PIN FILES

\begin{tabular}{|c|c|c|c|c|c|c|c|c|c|}
\hline \multirow[t]{2}{*}{ PIN\# } & \multirow[t]{2}{*}{ Accum. Pt } & \multirow{2}{*}{$\begin{array}{l}\text { Point of } \\
\text { Origin }\end{array}$} & \multirow{2}{*}{$\begin{array}{c}\text { Weight } \\
(\mathrm{Kg})\end{array}$} & \multirow{2}{*}{$\frac{\text { Volume. }}{\left(\mathrm{m}^{3}\right)}$} & \multirow{2}{*}{$\frac{6 \mathrm{pt}}{(\mathrm{mr} / \mathrm{hr})}$} & \multicolumn{2}{|c|}{ ASSAY } & \multirow{2}{*}{$\begin{array}{c}\text { SAMPLE } \\
\text { Tot. Act. } \\
\text { (pCi/g) }\end{array}$} & \multirow{2}{*}{$\begin{array}{l}\text { MAJOR CONTENTS } \\
\text { (see below) }\end{array}$} \\
\hline & & & & & & $\begin{array}{r}\text { Cs-137 } \\
\quad(p c)\end{array}$ & $\begin{array}{l}\text { Co-60 } \\
g)\end{array}$ & & \\
\hline $93-091-02$ & AY & $A P, A W, A Y$ & 292 & 4.0 & $<0.5$ & & & & $1,2,3,4$ \\
\hline $93-102-02$ & AY & $\mathrm{C}, \mathrm{AN}, \mathrm{AY}$ & 321 & 4.0 & $<0.5$ & & & & $1,2,3,4$ \\
\hline $93-105-12$ & AY & A & 320 & 4.0 & & & & & $1,2,3,4,9$ \\
\hline $93-105-13$ & AY & A & 978 & 4.0 & $<0.5$ & & & & $3,4,5,6$ \\
\hline $93-109-08$ & AY & A & 452 & 4.0 & & & & $<50$ & $1,2,3$ \\
\hline $93-109-09$ & AY & AY & 669 & 4.0 & $<0.2$ & & & & $1,2,3,4,5,6$ \\
\hline $93-109-14$ & AY & $A, A Y$ & 778 & 4.0 & & & & & 5,6 \\
\hline $93-110-01$ & AY & $A, A Y, A Z$ & 328 & 4.0 & $<0.2$ & & & & $1,2,3,4$ \\
\hline $93-111-01$ & $A Y$ & AY & 595 & 4.0 & $<0.2$ & & & & $5,6,7$ \\
\hline $93-111-13$ & AY & $A, A X, A Y$ & 867 & 4.0 & $<0.2$ & & & & $1,3,5,6$ \\
\hline $93-127-06$ & AY & A & 244 & 4.0 & $<0.2$ & & & & $1,2,3,4,5$ \\
\hline $93-130-01$ & AY & $A$ & 573 & 4.0 & 0.5 & 270 & 0.7 & & $1,2,3,4,5,6$ \\
\hline 93-144-01 & AY & AY & 37.2 & 0.2 & $<0.5$ & 1.1 & $<1.1$ & $<50$ & 9 \\
\hline $93-144-02$ & AY & AY & 31.3 & 0.2 & $<0.5$ & 1.3 & $<1.6$ & $<50$ & 9 \\
\hline $93-144-03$ & AY & AY & 36.7 & 0.2 & $<0.5$ & 1.6 & $<1.2$ & $<50$ & 9 \\
\hline $93-165-01$ & AY & $A, A Y$ & 604 & 4.0 & $<0.2$ & & & & $1,2,3,4$ \\
\hline $93-221-01$ & AY & A & 367 & 4.0 & $<0.2$ & & & & $1,2,3,4,8$ \\
\hline 93-316-01 & AY & AY & 415 & 4.0 & $<0.5$ & 270 & 0.91 & & $1,2,3,4,5$ \\
\hline $93-349-04$ & AY & $A, A X, A Z$ & 300 & 4.0 & $<0.5$ & 170 & 5.4 & & $1,2,3,4$ \\
\hline $94-089-02$ & AY & & 269 & 4.0 & $<0.5$ & 22 & 2.1 & & $1,2,3,4$ \\
\hline $94-104-02$ & AY & AY & 49.0 & 0.2 & $<0.5$ & & & & 5,9 \\
\hline
\end{tabular}


TANK FARMS LLW

93/94 HISTORICAL PIN FILES

\begin{tabular}{|c|c|c|c|c|c|c|c|c|}
\hline PIN \# & Accum. Pt & $\begin{array}{l}\text { Point of } \\
\text { Origin }\end{array}$ & Weight & Volume & $6 \mathrm{pt}$. & ASSAY & SAMPLE & MAJOR CONTENTS \\
\hline & & & $(\mathrm{Kg})$ & $\left(\mathrm{m}^{3}\right)$ & $(\mathrm{mr} / \mathrm{hr})$ & $\begin{array}{c}\text { Cs-137 }{ }^{\text {(pci/g) }}{ }^{\text {Co-60 }}\end{array}$ & $\begin{array}{l}\text { Tot. Act. } \\
\text { (pCi/g) }\end{array}$ & (see below) \\
\hline $94-159-03$ & AY & & 383 & 4.0 & $<0.5$ & & & $1,2,3,4,5$ \\
\hline $94-159-04$ & $A Y$ & & 382 & 4.0 & $<0.5$ & & & $1,2,3,4,5$ \\
\hline $94-158-02$ & $A Y$ & $701-A$ & 301 & 0.2 & $<0.5$ & & & 7 \\
\hline $94-158-03$ & AY & $701-A$ & 265 & 0.2 & $<0.5$ & & & 7 \\
\hline $94-165-04$ & AY & $701-A$ & 292 & 0.2 & $<0.5$ & & & 7, SOIL \\
\hline $94-165-05$ & AY & $701-A$ & 292 & 0.2 & $<0.5$ & & $<50$ & SOIL \\
\hline $94-173-04$ & AY & $701-A$ & 315 & 0.2 & $<0.5$ & & & 7, SOIL \\
\hline $94-173-05$ & AY & $701-A$ & 310 & 0.2 & $<0.5$ & & $<50$ & SOIL \\
\hline $94-174-01$ & AY & $701-A$ & 319 & 0.2 & $<0.5$ & & $<50$ & SOIL \\
\hline $94-174-02$ & AY & $701-A$ & 333 & 0.2 & $<0.5$ & & $<50$ & SOIL \\
\hline $94-174-03$ & AY & $701-A$ & 328 & 0.2 & $<0.5$ & & $<50$ & SOIL \\
\hline $94-208-04$ & AY & & 255 & 4.0 & $<0.5$ & & & $1,2,3,4,5$ \\
\hline $94-271-03$ & AY & & 405 & 4.0 & $<0.5$ & & & $1,2,3,4,5,6$ \\
\hline $94-293-12$ & AY & $701-A$ & 142 & 0.2 & $<0.5$ & & $<50$ & 7 \\
\hline
\end{tabular}


TANK FARMS LLW

93/94 HISTORICAL PIN FILES

\begin{tabular}{|c|c|c|c|c|c|c|c|c|c|}
\hline PIN \# & Accum. Pt & $\begin{array}{c}\text { Point of } \\
\text { Origin }\end{array}$ & Weight & Volume. & $6 \mathrm{pt}$. & \multicolumn{2}{|c|}{ ASSAY } & SAMPLE & MAJOR CONTENTS \\
\hline & & & $(\mathrm{Kg})$ & $\left(m^{3}\right)$ & $(\mathrm{mr} / \mathrm{hr})$ & $\begin{array}{r}\text { Cs-137 } \\
\text { (p }\end{array}$ & g) & $\begin{array}{l}\text { Tot. Act. } \\
\text { (pCi/g) }\end{array}$ & (see below) \\
\hline $93-105-23$ & B & B & 188 & 4.0 & $<0.5$ & $<1.6$ & 1.70 & & $1,2,3,4,9$ \\
\hline $93-105-24$ & B & $B$ & 87 & 4.0 & $<0.5$ & & & & $1,2,3,4,5,7,8,9$ \\
\hline
\end{tabular}


TANK FARMS LLW

93/94 HISTORICAL PIN FILES

\begin{tabular}{|c|c|c|c|c|c|c|c|c|}
\hline PIN \# & Accum. Pt & $\begin{array}{l}\text { Point of } \\
\text { Origin }\end{array}$ & Weight & Volume & $6 \mathrm{pt}$ & ASSAY & SAMPLE & MAJOR CONTENTS \\
\hline & & & $(\mathrm{Kg})$ & $\left(m^{3}\right)$ & $(\mathrm{mr} / \mathrm{hr})$ & $\begin{array}{c}\mathrm{Cs}-137 \quad \mathrm{Co}-60 \\
(\mathrm{pCi} / \mathrm{g})\end{array}$ & $\begin{array}{l}\text { Tot. Act. } \\
(\mathrm{pCi} / \mathrm{g})\end{array}$ & (see below) \\
\hline $93-105-06$ & $\mathrm{BX}$ & $B X, B Y$ & 286 & 4.0 & & & & $1,2,3,6$ \\
\hline $93-105-07$ & $\mathrm{BX}$ & $B X, B Y$ & 462 & 4.0 & $<0.5$ & & & $1,2,3,4,5,6$ \\
\hline $93-111-02$ & $\mathrm{BX}$ & $B X$ & 1039 & 4.0 & $<0.5$ & & & $5,6,9$ \\
\hline $93-111-03$ & $B X$ & BX & 1289 & 4.0 & $<0.5$ & & & 5,7 \\
\hline $93-112-02$ & $B X$ & $B X, B Y$ & 539 & 4.0 & $<0.2$ & & & $1,2,3,4,5,6$ \\
\hline $93-112-03$ & $\mathrm{BX}$ & BX & 381 & 4.0 & & & & $1,2,3,4$ \\
\hline $93-116-09$ & $B X$ & $B X, B Y$ & 286 & 4.0 & $<0.2$ & & & $1,2,3,4$ \\
\hline $93-116-10$ & $\mathrm{BX}$ & BX & 599 & 4.0 & $<0.2$ & & & $1,2,3,4,5,6$ \\
\hline $93-118-01$ & $\mathrm{BX}$ & $B X, B Y$ & 523 & 4.0 & $<0.5$ & & & $1,2,3,5,6$ \\
\hline $93-118-05$ & $\mathrm{BX}$ & $B X$ & 224 & 4.0 & $<0.5$ & & & $1,2,3,5,6$ \\
\hline $93-120-03$ & $\mathrm{BX}$ & $\mathrm{BX}$ & 615 & 4.0 & $<0.5$ & & & 6 \\
\hline $93-120-04$ & $\mathrm{BX}$ & $B X$ & 1532 & 4.0 & $<0.2$ & & & 5,6 \\
\hline $93-124-02$ & $B X$ & $\mathrm{BX}$ & 903 & 4.0 & $<0.2$ & & & $2,3,4,5$ \\
\hline $93-126-05$ & $\mathrm{BX}$ & $\mathrm{BX}$ & 1005 & 4.0 & $<0.2$ & & & $2,3,5,6$ \\
\hline $93-126-06$ & $B X$ & $B X$ & 1596 & 4.0 & $<0.2$ & & & $3,5,6$ \\
\hline $93-126-07$ & $B X$ & BX & 675 & 4.0 & $<0.2$ & & & 6 \\
\hline $93-134-01$ & $B X$ & $B X, B Y$ & 760 & 4.0 & $<0.2$ & & & $1,2,3,4,5,6,7$ \\
\hline $93-134-03$ & $\mathrm{BX}$ & $\mathrm{BX}, \mathrm{BY}$ & 651 & 4.0 & 1 & & & $1,2,3,4,5,6$ \\
\hline $93-190-01$ & $B X$ & $\mathrm{BX}, \mathrm{BY}$ & 369 & 4.0 & $<0.5$ & & & $1,2,3,4$ \\
\hline $93-200-02$ & $\mathrm{BX}$ & $\mathrm{BX}, \mathrm{BY}$ & 481 & 4.0 & $<0.2$ & & & $1,2,3,4,5$ \\
\hline $93-202-05$ & $\mathrm{BX}$ & $\mathrm{BX}$ & 553 & 4.0 & $<0.2$ & & & 6,9 \\
\hline
\end{tabular}


TANK FARMS LLW

93/94 HISTORICAL PIN FILES

\begin{tabular}{|c|c|c|c|c|c|c|c|c|c|}
\hline \multirow[t]{2}{*}{$\mathrm{P} \mid \mathrm{N} \#$} & \multirow[t]{2}{*}{ Accum. Pt } & \multirow{2}{*}{$\begin{array}{c}\text { Point of } \\
\text { Origin }\end{array}$} & \multirow{2}{*}{$\frac{\text { Weight }}{(\mathrm{Kg})}$} & \multirow{2}{*}{$\begin{array}{c}\text { Volume . } \\
\frac{\left(\mathrm{m}^{3}\right)}{}\end{array}$} & \multirow{2}{*}{$\begin{array}{c}6 \mathrm{pt} \\
(\mathrm{mr} / \mathrm{hr})\end{array}$} & \multicolumn{2}{|c|}{ ASSAY } & \multirow{2}{*}{$\begin{array}{c}\text { SAMPLE } \\
\text { Tot. Act. } \\
\text { (pCi/g) }\end{array}$} & \multirow[t]{2}{*}{ MAJOR CONTENTS } \\
\hline & & & & & & $\begin{array}{r}\text { Cs-137 } \\
\text { (p }\end{array}$ & $\begin{array}{l}\text { Co-60 } \\
\text { g) }\end{array}$ & & \\
\hline $93-202-06$ & $\mathrm{BX}$ & $\mathrm{BX}$ & 569 & 4.0 & $<0.2$ & & & & $4,6,9$ \\
\hline $93-204-01$ & $B X$ & $\mathrm{BX}$ & 583 & 4.0 & $<0.5$ & & & & 6,9 \\
\hline $93-204-02$ & $\mathrm{BX}$ & $\mathrm{BX}$ & 551 & 4.0 & $<0.5$ & & & & 6,9 \\
\hline $93-204-03$ & $\mathrm{BX}$ & $\mathrm{BX}$ & 562 & 4.0 & $<0.5$ & & & & 6,9 \\
\hline $93-210-02$ & $\mathrm{BX}$ & $\mathrm{BX}$ & 553 & 4.0 & $<0.2$ & & & & $4,6,9$ \\
\hline $93-210-03$ & $\mathrm{BX}$ & $\mathrm{BX}$ & 169 & 4.0 & $<0.2$ & & & & $1,2,3,4,5$ \\
\hline $93-210-04$ & $\mathrm{BX}$ & $\mathrm{BX}$ & 540 & 4.0 & $<0.2$ & & & & $5,6,7,9$ \\
\hline $93-210-05$ & $\mathrm{BX}$ & $\mathrm{BX}$ & 689 & 4.0 & $<0.2$ & & & & $1,2,3,4,5$ \\
\hline $93-215-01$ & $B X$ & $\mathrm{BX}$ & 1448 & 4.0 & $<0.5$ & & & & $2,4,5,6$ \\
\hline $93-277-01$ & $\mathrm{BX}$ & $B X, B Y$ & 215 & 4.0 & $<0.5$ & & & & $1,2,3,4,6$ \\
\hline $93-285-01$ & $\mathrm{BX}$ & $B X, B Y$ & 315 & 4.0 & $<0.5$ & & & & $1,2,3,4,5$ \\
\hline $94-035-01$ & $\mathrm{BX}$ & $B X, B Y$ & 188 & 4.0 & 0.7 & 12000 & 4.0 & & $1,2,3,4$ \\
\hline $94-074-02$ & $\mathrm{BX}$ & BXR & 1094 & 6.7 & $<0.5$ & & & & $3,5,6$ \\
\hline $94-108-02$ & $\mathrm{BX}$ & BXR & 492 & 4.0 & $<0.5$ & 130 & 0.6 & & $1,2,3,4,5$ \\
\hline $94-136-03$ & $B X$ & $\mathrm{BX}$ & 451 & 4.0 & $<0.5$ & 610 & 0.4 & & $1,2,3,4,5$ \\
\hline $94-151-01$ & $B X$ & $B X$ & 223 & 4.0 & $<0.5$ & & & & $1,2,3,4,5,6$ \\
\hline $94-178-01$ & $\mathrm{BX}$ & $\mathrm{BX}$ & 314 & 4.0 & $<0.5$ & & & & $1,2,3,4,5$ \\
\hline $94-206-01$ & $\mathrm{BX}$ & $\mathrm{BX}$ & 478 & 4.0 & $<0.5$ & & & & $1,2,3,4,5$ \\
\hline $94-252-01$ & $\mathrm{BX}$ & $\mathrm{BX}$ & 292 & 4.0 & $<0.5$ & & & & $1,2,3,4,5$ \\
\hline $94-270-09$ & $B X$ & $\mathrm{BX}$ & 392 & 4.0 & $<0.5$ & & & & $1,2,3,4,5$ \\
\hline
\end{tabular}


TANK FARMS LLW

93/94 HISTORICAL PIN FILES

\begin{tabular}{|c|c|c|c|c|c|c|c|c|c|}
\hline \multirow[t]{2}{*}{ PIN\# } & \multirow[t]{2}{*}{ Accum. $\mathrm{Pt}$} & \multirow[t]{2}{*}{$\begin{array}{c}\text { Point of } \\
\text { Origin } \\
\end{array}$} & \multirow{2}{*}{$\begin{array}{c}\text { Weight } \\
(\mathrm{Kg})\end{array}$} & \multirow{2}{*}{$\begin{array}{l}\text { Volume } \\
\frac{\left(m^{3}\right)}{}\end{array}$} & \multirow{2}{*}{$\begin{array}{c}6 \mathrm{pt} . \\
(\mathrm{mr} / \mathrm{hr})\end{array}$} & \multicolumn{2}{|c|}{ ASSAY } & \multirow{2}{*}{$\begin{array}{c}\text { SAMPLE } \\
\text { Tot. Act. } \\
\text { (pCi/g) }\end{array}$} & \multirow{2}{*}{$\begin{array}{l}\text { MAJOR CONTENTS } \\
\text { (see below) }\end{array}$} \\
\hline & & & & & & $\begin{array}{r}\mathrm{Cs}-137 \\
(\mathrm{pC}\end{array}$ & $\begin{array}{l}{ }^{C 0-60} \\
\mathrm{i} / \mathrm{g})\end{array}$ & & \\
\hline $93-105-28$ & $c$ & $\mathrm{C}$ & 354 & 4.0 & & & & & $1,2,3,4$ \\
\hline $93-105-29$ & C & $\mathrm{C}$ & 660 & 4.0 & & & & & $1,2,3,4,5,6$ \\
\hline $93-110-19$ & $c$ & C & 204 & 4.0 & $<0.5$ & 221.0 & 1.80 & & $1,2,3,4$ \\
\hline $93-110-20$ & $c$ & C & 437 & 4.0 & $<0.5$ & & & & $3,4,5,6$ \\
\hline $93-111-04$ & c & C & 394 & 4.0 & $<0.5$ & & & & $1,3,4,5,6$ \\
\hline $93-111-09$ & C & $\mathrm{C}$ & 805 & 4.0 & $<0.2$ & & & & $3,5,6$ \\
\hline $93-111-10$ & c & $\mathrm{C}$ & 669 & 4.0 & $<0.5$ & & & & $3,4,5,6,7,9$ \\
\hline $93-113-04$ & C & $\mathrm{C}$ & 218 & 4.0 & $<0.2$ & & & & $1,2,3,4,9$ \\
\hline $93-113-05$ & $\mathrm{C}$ & C & 762 & 4.0 & $<0.2$ & & & & $1,2,3,4,5,6$ \\
\hline $93-167-02$ & C & $\mathrm{C}$ & 184 & 4.0 & $<0.2$ & & & & $3,8,9$ \\
\hline $93-207-01$ & $c$ & C & 132 & 4.0 & $<0.5$ & & & & FOAM, 9 \\
\hline $93-207-02$ & C & $106-C$ & 152 & 4.0 & $<0.5$ & 1700 & $<1.2$ & & FOAM, 9 \\
\hline $93-209-01$ & $\mathrm{C}$ & $106-c$ & 274 & 4.0 & $<0.5$ & & & & $1,2,3,4$ \\
\hline $93-270-01$ & $\mathrm{C}$ & C & 255 & 4.0 & $<0.2$ & & & & $1,2,3,4,9$ \\
\hline $93-278-01$ & $\mathrm{C}$ & $\mathrm{C}$ & 413 & 4.0 & 5.0 & 17000.0 & $<0.56$ & 144000.0 & $2,3,4,6,8$ \\
\hline $93-278-01$ & $\mathrm{C}$ & c & SAMP & E DATA-- & $\ldots$ & (GEA): $:^{137} \mathrm{Cs}$ & $9.23 \mathrm{EO}$ & Sr: $2.85 \mathrm{E} 02$ & \\
\hline $93-312-01$ & $\mathrm{C}$ & C & 169 & 4.0 & $<0.5$ & & & & $1,2,3,4,9$ \\
\hline $93-362-01$ & $\mathrm{C}$ & C & 233 & 4.0 & $<0.5$ & & & & $1,2,3,4,9$ \\
\hline $94-019-02$ & $\mathrm{C}$ & $\mathrm{C}$ & 483 & 4.0 & $<0.5$ & 270 & 0.69 & & $1,2,3,4,5,9$ \\
\hline $94-048-01$ & $\mathrm{C}$ & $\mathrm{C}$ & 306 & 4.0 & $<0.5$ & 190 & 1.7 & & $1,2,3,4,9$ \\
\hline $94-088-02$ & c & C & 319 & 4.0 & $<0.5$ & & & & $1,2,3,4,5,6,9$ \\
\hline
\end{tabular}


TANK FARMS LLW

93/94 HISTORICAL PIN FILES

\begin{tabular}{|c|c|c|c|c|c|c|c|c|c|}
\hline \multirow[t]{2}{*}{ PIN \# } & \multirow[t]{2}{*}{ Accum. Pt } & \multirow{2}{*}{$\begin{array}{l}\text { Point of } \\
\text { Origin }\end{array}$} & \multirow{2}{*}{$\frac{\text { Weight }}{(\mathrm{Kg})}$} & \multirow{2}{*}{ Volume } & \multirow{2}{*}{$\begin{array}{c}6 \mathrm{pt} . \\
(\mathrm{mr} / \mathrm{hr})\end{array}$} & \multicolumn{2}{|c|}{ ASSAY } & \multirow{2}{*}{$\begin{array}{c}\text { SAMPLE } \\
\text { Tot. Act. } \\
\text { (pCi/g) }\end{array}$} & \multirow{2}{*}{$\frac{\text { MAJOR CONTENTS }}{\text { (see below) }}$} \\
\hline & & & & & & $\begin{array}{r}\text { Cs-137 } \\
\text { (p }\end{array}$ & $\begin{array}{l}\text { Co-60 } \\
\text { g) }\end{array}$ & & \\
\hline $94-115-03$ & c & $244-C$ & 198 & 0.2 & $<0.5$ & 460 & 0.53 & & $1,2,3,4,9$ \\
\hline $94-129-01$ & c & c & 396 & 4.0 & $<0.5$ & 87 & 0.35 & & $1,2,3,4,5,9$ \\
\hline $94-137-02$ & C & $\mathrm{C}$ & 460 & 4.0 & $<0.5$ & 610 & 0.38 & & $1,2,3,4,5,9$ \\
\hline $94-147-02$ & $\mathrm{c}$ & $\mathrm{C}$ & 329 & 4.0 & $<0.5$ & & & & $1,2,3,4,5,6,9$ \\
\hline $94-173-02$ & c & $\mathrm{c}$ & 292 & 4.0 & $<0.5$ & & & & $1,2,3,4,5,9$ \\
\hline $94-193-02$ & C & C & 339 & 4.0 & $<0.5$ & & & & $1,2,3,4,5,9$ \\
\hline $94-242-01$ & C & $c$ & 373 & 4.0 & $<0.5$ & & & & $1,2,3,4,5,9$ \\
\hline $94-270-01$ & C & $\mathrm{C}$ & 369 & 4.0 & $<0.5$ & & & & $1,2,3,4,5,6,9$ \\
\hline $94-292-02$ & c & $\mathrm{C}$ & 632 & 4.0 & $<0.5$ & & & & $1,2,3,4,5,9$ \\
\hline
\end{tabular}


TANK FARMS LLW

93/94 HISTORICAL PIN FILES

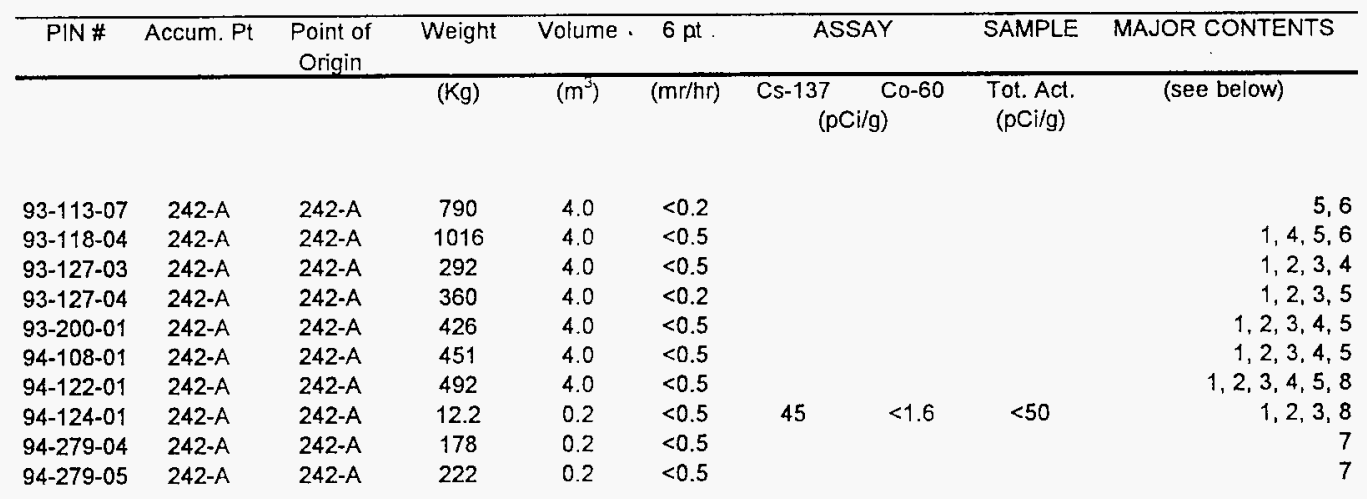


TANK FARMS LLW

93/94 HISTORICAL PIN FILES

\begin{tabular}{ccccccccr}
\hline PIN \# & Accum. Pt & $\begin{array}{c}\text { Point of } \\
\text { Origin }\end{array}$ & Weight & Volume & $6 \mathrm{pt}$ & ASSAY & SAMPLE & MAJOR CONTENTS \\
\hline & & & $(\mathrm{Kg})$ & $\left(\mathrm{m}^{3}\right)$ & $(\mathrm{mr} / \mathrm{hr})$ & $\begin{array}{c}\text { Cs-137 } \\
\text { (pCi/g) }\end{array}$ & $\begin{array}{c}\text { Co-60 } \\
\text { (pCi/g) }\end{array}$ & (set. Act. \\
& & & & & & & & \\
$93-118-03$ & $204-A R$ & $204-A R$ & 269 & 4.0 & $<0.5$ & & $1,2,3,4$ \\
$93-153-02$ & $204-A R$ & 204-AR & 208 & 4.0 & $<0.5$ & & $1,2,3,4$ \\
$94-082-03$ & $204-A R$ & 204-AR & 419 & 4.0 & $<0.5$ & & $1,2,3,4,5$
\end{tabular}


TANK FARMS LLWW

93/94 HISTORICAL PIN FILES

\begin{tabular}{cccccccccc}
\hline PIN \# & Accum. Pt & $\begin{array}{c}\text { Point of } \\
\text { Origin }\end{array}$ & Weight & Volume & $6 \mathrm{pt}$ & ASSAY & SAMPLE & MAJOR CONTENTS \\
\hline & & $(\mathrm{Kg})$ & $\left(\mathrm{m}^{3}\right)$ & $(\mathrm{mr} / \mathrm{hr})$ & $\begin{array}{c}\mathrm{Cs}-137 \\
(\mathrm{pCi} / \mathrm{g})\end{array}$ & $\begin{array}{c}\text { Co-60 } \\
\text { (pCi/g) }\end{array}$ & (see below) \\
$94-018-02$ & $209-\mathrm{E}$ & $209-\mathrm{E}$ & 34.5 & 0.2 & $<0.2$ & 5.9 & 9.80 & 11.10 & $1,2,9$
\end{tabular}


TANK FARMS LLW

93/94 HISTORICAL PIN FILES

\begin{tabular}{|c|c|c|c|c|c|c|c|c|c|}
\hline \multirow[t]{2}{*}{$P I N \#$} & \multirow[t]{2}{*}{ Accum. Pt } & \multirow{2}{*}{$\begin{array}{c}\text { Point of } \\
\text { Origin }\end{array}$} & \multirow{2}{*}{$\begin{array}{l}\text { Weight } \\
(\mathrm{Kg})\end{array}$} & \multirow{2}{*}{$\begin{array}{l}\text { Volume. } \\
\frac{\left(\mathrm{m}^{3}\right)}{}\end{array}$} & \multirow{2}{*}{$\begin{array}{c}6 \mathrm{pt} . \\
(\mathrm{mr} / \mathrm{hr})\end{array}$} & \multicolumn{2}{|c|}{ ASSAY } & \multirow{2}{*}{$\begin{array}{c}\text { SAMPLE } \\
\text { Tot. Act. } \\
(\mathrm{pCi} / \mathrm{g})\end{array}$} & MAJOR CONTENTS \\
\hline & & & & & & \multicolumn{2}{|c|}{$(\mathrm{pCi} / \mathrm{g})$} & & (see below) \\
\hline 93-039-03 & $S$ & SY & 580 & 4.0 & $<0.2$ & 380 & $<0.19$ & & $2,4,5,6$ \\
\hline $93-095-07$ & $S$ & SY & 191 & 4.0 & & 350 & 1.1 & & $1,2,3,4$ \\
\hline $93-095-08$ & $\mathrm{~S}$ & SY & 210 & 4.0 & & 3800 & 0.17 & & Eu-154: $22 \quad 1,2,3,4$ \\
\hline $93-095-09$ & $\mathbf{S}$ & SY & 224 & 4.0 & $<0.2$ & 32 & 1 & & $1,2,3,4,5,6,9$ \\
\hline $93-095-10$ & $S$ & SY & 633 & 4.0 & & & & & $1,2,3,4$ \\
\hline $93-103-01$ & $s$ & $s$ & 646 & 4.0 & $<0.2$ & 30 & $<0.14$ & & $1,2,3,4,5,6,9$ \\
\hline $93-103-02$ & $\mathbf{s}$ & $S$ & 283 & 4.0 & & 0.57 & 2.1 & & $1,2,3,4$ \\
\hline $93-104-04$ & $\mathrm{~S}$ & $S$ & 757 & 4.0 & $<0.2$ & 23 & $<0.16$ & & $3,4,5,6$ \\
\hline $93-107-01$ & $\mathrm{~s}$ & $S$ & 301 & 4.0 & & 40 & $<0.41$ & & $1,2,3,4$ \\
\hline $93-107-02$ & 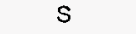 & $\mathrm{S}$ & 227 & 4.0 & & & & & $1,2,3$ \\
\hline $93-107-03$ & $S$ & $S$ & 865 & 4.0 & $<0.2$ & 25 & $<0.17$ & & $1,2,3,5,6,9$ \\
\hline $93-107-04$ & S & $S$ & 604 & 4.0 & $<0.2$ & 13 & $<0.27$ & & $1,3,4,5,9$ \\
\hline $93-107-06$ & $S$ & $S$ & 422 & 4.0 & $<0.2$ & 120 & $<0.27$ & & $1,2,3,5,6,9$ \\
\hline $93-109-13$ & $s$ & $242-S$ & 24 & 0.2 & $<0.5$ & 24 & $<18$ & $<50$ & $1,5,9$, OlL \\
\hline $93-110-12$ & $S$ & $s$ & 825 & 4.0 & $<0.2$ & 0.18 & 0.47 & & $1,2,3,5,6,9$ \\
\hline $93-110-14$ & $S$ & $s$ & 26 & 0.2 & $<0.5$ & 6.3 & $<1.7$ & $2.93 \mathrm{E}-05$ & 1,9 , OIL \\
\hline $93-110-31$ & $S$ & SY & 249 & 4.0 & $<0.2$ & 0.88 & $<0.52$ & & $1,2,3,5,6,9$ \\
\hline $93-110-39$ & $\mathrm{~S}$ & $S$ & 538 & 4.0 & $<0.2$ & 270 & $<0.21$ & & $1,2,3,4,5,6,9$ \\
\hline $93-110-40$ & $S$ & $S$ & 223 & 4.0 & $<0.2$ & 10 & 0.46 & & $3,8,9$ \\
\hline $93-110-41$ & $S$ & $s$ & 286 & 4.0 & $<0.2$ & 100 & 3.5 & & $1,2,3,4,9$ \\
\hline $93-119-02$ & $S$ & $S$ & 310 & 4.0 & & & & & $1,2,3,4,9$ \\
\hline $93-119-03$ & $S$ & $S$ & 787 & 4.0 & 1 & 3500 & 0.83 & & $1,3,4,5,6,9$ \\
\hline & & & & & & Eu-154: 2 & Eu-155: & 3000 & \\
\hline
\end{tabular}


TANK FARMS LLW

93/94 HISTORICAL PIN FILES

\begin{tabular}{|c|c|c|c|c|c|c|c|c|c|}
\hline \multirow[t]{2}{*}{$\mathrm{P} \backslash \mathrm{N} \#$} & \multirow[t]{2}{*}{ Accum. Pt } & \multirow[t]{2}{*}{$\begin{array}{c}\text { Point of } \\
\text { Origin }\end{array}$} & \multirow{2}{*}{$\frac{\text { Weight }}{(\mathrm{Kg})}$} & \multirow{2}{*}{$\frac{\text { Volume . }}{\left(\mathrm{m}^{3}\right)}$} & \multirow{2}{*}{$\frac{6 \mathrm{pt} .}{(\mathrm{mr} / \mathrm{hr})}$} & \multicolumn{2}{|c|}{ ASSAY } & \multirow{2}{*}{$\begin{array}{c}\text { SAMPLE } \\
\begin{array}{c}\text { Tot. Act. } \\
(\mathrm{pCi} / \mathrm{g})\end{array}\end{array}$} & \multirow{2}{*}{$\begin{array}{l}\text { MAJOR CONTENTS } \\
\text { (see below) }\end{array}$} \\
\hline & & & & & & $\begin{array}{r}\text { Cs-137 } \\
\text { (p }\end{array}$ & g) & & \\
\hline $93-138-02$ & $s$ & s & 302 & 4.0 & $<0.2$ & 300 & 2.1 & & $1,2,3,4,9$ \\
\hline $93-160-02$ & $s$ & SISXISY & 535 & 4.0 & $<0.5$ & & & & $1,2,3,4,5,6,9$ \\
\hline $93-165-02$ & $\mathrm{~s}$ & SY & 216 & 4.0 & $<0.2$ & & & & $1,2,3,4,9$ \\
\hline $93-179-03$ & $s$ & SY & 192 & 4.0 & $<0.2$ & & & & $1,2,3,4,9$ \\
\hline $93-179-04$ & s & SY & 585 & 4.0 & $<0.2$ & & & & $1,2,3,4,5,6,9$ \\
\hline $93-181-02$ & S & S-COMP. & 377 & 4.0 & $<0.2$ & & & & $1,2,3,4,9$ \\
\hline $93-195-03$ & $s$ & S-COMP. & 363 & 4.0 & $<0.2$ & & & & $1,2,3,4,9$ \\
\hline $93-267-01$ & s & $s$ & 239 & 4.0 & $<0.2$ & & & & $1,2,3,4,9$ \\
\hline $93-312-02$ & s & S-COMP. & 371 & 4.0 & $<0.5$ & & & & $1,2,3,4,5,8,9$ \\
\hline $93-319-01$ & s & SISXISY & 321 & 4.0 & $<0.2$ & & & & $1,2,3,4,5,6,9$ \\
\hline $93-321-02$ & $s$ & SXISY & 352 & 4.0 & $<0.2$ & & & & $1,2,3,4,5,9$ \\
\hline $93-363-02$ & $\mathrm{~s}$ & S-COMP. & 273 & 4.0 & $<0.2$ & 810 & 3.1 & & $1,2,3,4,9$ \\
\hline 94-003-01 & S & S & 1045 & 4.0 & $<0.5$ & & & & 6,9 \\
\hline $94-003-02$ & s & S & 975 & 4.0 & $<0.5$ & & & & 6,9 \\
\hline $94-066-01$ & s & S-COMP. & 969 & 4.0 & $<0.5$ & & & & $3,4,5,6,9$ \\
\hline $94-082-02$ & s & SY & 344 & 4.0 & $<0.5$ & & & & $1,2,3,4,5,6,9$ \\
\hline $94-109-01$ & s & S-COMP. & 369 & 4.0 & $<0.5$ & 330 & 2.1 & & $1,2,3,4,5,6,9$ \\
\hline $94-139-03$ & $s$ & S-COMP. & 450 & 4.0 & $<0.5$ & & & & $1,2,3,4,5,6,8,9$ \\
\hline $94-168-01$ & $s$ & S-COMP. & 492 & 4.0 & $<0.5$ & & & & $1,2,3,4,5,6,9$ \\
\hline
\end{tabular}


TANK FARMS LLW

93/94 HISTORICAL PIN FILES

\begin{tabular}{cccccc}
\hline PIN \# & Accum. Pt & $\begin{array}{c}\text { Point of } \\
\text { Origin }\end{array}$ & Weight & Volume & $6 \mathrm{pt}$ \\
\hline \multicolumn{7}{c}{} & & $(\mathrm{Kg})$ & $\left(\mathrm{m}^{3}\right)$ & $(\mathrm{mr} / \mathrm{hr})$ \\
& & & & \\
$94-171-01$ & S & SY & 351 & 4.0 & $<0.5$ \\
$94-227-01$ & S & S-COMP & 260 & 4.0 & $<0.5$ \\
$94-243-01$ & S & SY & 623 & 4.0 & $<0.5$ \\
$94-243-02$ & S & SY & 564 & 4.0 & $<0.5$ \\
$94-244-02$ & S & SY & 855 & 4.0 & $<0.5$ \\
$94-244-03$ & S & SY & 21 & 0.2 & $<0.5$ \\
$94-244-04$ & S & SY & 26 & 0.2 & $<0.5$ \\
$94-244-04$ & S & SY & 26 & 0.2 & $<0.5$ \\
$94-249-01$ & S & SY & 296 & 4.0 & $<0.5$ \\
$94-249-02$ & S & S-COMP. & 368 & 4.0 & $<0.5$ \\
$94-250-01$ & S & S & 619 & 4.0 & $<0.5$ \\
$94-269-01$ & S & SY & 269 & 4.0 & $<0.5$ \\
$94-277-01$ & S & S-COMP. & 405 & 4.0 & $<0.5$
\end{tabular}

$1,2,3,4,5,6,9$

$1,2,3,4,5,6,9$

$5,6,9$

$5,6,9$

$2,3,5,6$

$1,3,6,9$, OlL

$1,2,3,5,9$, OIL

$1,2,3,5,9$, OIL

$1,2,3,4,5,6,9$

$1,2,3,4,5,6,9$

$1,2,3,4,5,6,9$

$1,2,3,4,5,6,9$

$1,2,3,4,5,6,9$ 
TANK FARMS LLW

93/94 HISTORICAL PIN FILES

\begin{tabular}{|c|c|c|c|c|c|c|c|c|c|}
\hline \multirow[t]{2}{*}{ PIN \# } & \multirow[t]{2}{*}{ Accum. Pt } & \multirow{2}{*}{$\begin{array}{c}\text { Point of } \\
\text { Origin }\end{array}$} & \multirow{2}{*}{$\frac{\text { Weight }}{(\mathrm{Kg})}$} & \multirow{2}{*}{$\begin{array}{c}\text { Volume } \\
\frac{\left(\mathrm{m}^{3}\right)}{}\end{array}$} & \multirow{2}{*}{$\frac{6 \mathrm{pt} .}{(\mathrm{mr} / \mathrm{hr})}$} & \multicolumn{2}{|c|}{ ASSAY } & \multirow{2}{*}{$\begin{array}{c}\text { SAMPLE } \\
\text { Tot. Act. } \\
\text { (pCi/g) }\end{array}$} & \multirow{2}{*}{$\begin{array}{l}\text { MAJOR CONTENTS } \\
\text { (see below) }\end{array}$} \\
\hline & & & & & & $\begin{array}{r}\text { Cs-137 } \\
(p\end{array}$ & $\begin{array}{l}\text { Co-60 } \\
g)\end{array}$ & & \\
\hline $93-090-01$ & $s x$ & $701 \mathrm{Bldg}$ & 1646 & 4.0 & & 0.29 & $<0.23$ & & $3,6,7$ \\
\hline $93-090-03$ & $s x$ & 701 Bldg & 1744 & 4.0 & $<0.2$ & 0.26 & $<0.19$ & & 5 \\
\hline $93-104-06$ & sX & $s X$ & 1535 & 4.0 & $<0.2$ & 0.25 & $<0.18$ & & $1,2,3,4,5$ \\
\hline $93-104-09$ & SX & $701 \mathrm{Bldg}$ & 1694 & 4.0 & $<0.2$ & 0.31 & $<0.21$ & & $5,6,7$ \\
\hline $93-110-27$ & $s x$ & sx & 1048 & 4.0 & $<0.2$ & 0.25 & $<0.19$ & & 5 \\
\hline $93-110-28$ & $s x$ & $s x$ & 440 & 4.0 & $<0.2$ & 0.36 & $<0.25$ & & 5,6 \\
\hline $93-110-29$ & $s x$ & $s x$ & 383 & 4.0 & $<0.2$ & 0.34 & $<0.32$ & & 5,9 \\
\hline $93-119-01$ & $s x$ & S/SX/SY & 302 & 4.0 & & & & & $1,2,3,4,5,9$ \\
\hline $93-110-30$ & $s x$ & $s x$ & 511 & 4.0 & & 0.25 & 0.19 & & $3,5,6,9$ \\
\hline $93-363-01$ & $s x$ & S/SX & 569 & 4.0 & 0.8 & 2700 & 5.3 & & $1,2,3,4,5,9$ \\
\hline $94-031-02$ & $s x$ & S-COMP. & 279 & 4.0 & $<0.5$ & 610 & 10.00 & & $1,2,3,4,9$ \\
\hline $94-088-01$ & $s x$ & S-COMP. & 627 & 4.0 & $<0.5$ & 57 & 1.90 & & $1,2,3,4,5,9$ \\
\hline
\end{tabular}


TANK FARMS LLW

93/94 HISTORICAL PIN FILES

\begin{tabular}{|c|c|c|c|c|c|c|c|c|c|}
\hline \multirow[t]{2}{*}{ PIN \# } & \multirow[t]{2}{*}{ Accum. $\mathrm{Pt}$} & \multirow{2}{*}{$\begin{array}{c}\text { Point of } \\
\text { Origin }\end{array}$} & \multirow{2}{*}{$\begin{array}{c}\text { Weight } \\
(\mathrm{Kg})\end{array}$} & \multirow{2}{*}{$\frac{\text { Volume }}{\left(\mathrm{m}^{3}\right)}$} & \multirow{2}{*}{$\begin{array}{c}6 \mathrm{pt} . \\
(\mathrm{mr} / \mathrm{hr})\end{array}$} & \multicolumn{2}{|c|}{ ASSAY } & \multirow{2}{*}{$\begin{array}{c}\text { SAMPLE } \\
\text { Tot. Act. } \\
(p \mathrm{Ci} / \mathrm{g})\end{array}$} & \multirow[t]{2}{*}{ MAJOR CONTENTS } \\
\hline & & & & & & $\begin{array}{r}\text { Cs-137 } \\
\text { (p }\end{array}$ & g) & & \\
\hline 93-103-07 & $\top$ & $\mathrm{T}$ & 204 & 4.0 & $<0.2$ & 11 & 2.30 & & $1,2,3,4,8,9$ \\
\hline $93-103-08$ & $T$ & $\mathrm{~T}$ & 355 & 4.0 & $<0.5$ & 780 & 0.70 & & $1,2,4,5,9$ \\
\hline $93-110-21$ & $\mathrm{~T}$ & $\mathrm{~T}$ & 39 & 4.0 & $<0.2$ & & & & 8 \\
\hline $93-160-01$ & $T$ & $\mathrm{~T}$ & 312 & 4.0 & $<0.2$ & 10 & 5.40 & & $1,2,3,4,9$ \\
\hline $93-165-03$ & $T$ & $\mathrm{~T}$ & 255 & 4.0 & $<0.5$ & 40 & 4.30 & & $1,2,3,4,9$ \\
\hline $94-103-01$ & $T$ & $\mathrm{~T}$ & 551 & 4.0 & $<0.2$ & 95 & 0.47 & & $1,2,3,4,5,9$ \\
\hline $94-125-02$ & $\mathrm{~T}$ & T & 473 & 4.0 & $<0.5$ & & & & $1,2,3,4,5,6,9$ \\
\hline $94-130-05$ & $\mathrm{~T}$ & $T$ & 587 & 4.0 & $<0.5$ & 0.6 & $<0.28$ & & 6 \\
\hline
\end{tabular}

Contents Legend:

1-Cloth, 2-Paper, 3-Plastic, 4-Rubber, 5-Mefal, 6-Wood, 7-Concrete/Asphalt, 8-Vegetation, 9-Absorbent 


\section{ATTACHMENT A}

TANK FARMS LLW

93/94 HISTORICAL PIN FILES

\begin{tabular}{|c|c|c|c|c|c|c|c|c|c|}
\hline \multirow[t]{2}{*}{ PIN \# } & \multirow[t]{2}{*}{ Accum. $\mathrm{Pt}$} & \multirow{2}{*}{$\begin{array}{c}\text { Point of } \\
\text { Origin }\end{array}$} & \multirow{2}{*}{$\frac{\text { Weight }}{(\mathrm{Kg})}$} & \multirow{2}{*}{$\frac{\text { Volume }}{\left(\mathrm{m}^{3}\right)}$} & \multirow{2}{*}{$\frac{6 \mathrm{pt} .}{(\mathrm{mr} / \mathrm{hr})}$} & \multicolumn{2}{|c|}{ ASSAY } & \multirow{2}{*}{$\begin{array}{c}\text { SAMPLE } \\
\begin{array}{c}\text { Tot. Act. } \\
\text { (pCi/g) }\end{array}\end{array}$} & \multirow{2}{*}{$\frac{\text { MAJOR CONTENTS }}{\text { (see below) }}$} \\
\hline & & & & & & Cs-137 & g) & & \\
\hline $93-103-05$ & $T X$ & $T X$ & 632 & 4.0 & $<0.2$ & 1.5 & $<.17$ & & $2,5,6,9$ \\
\hline $93-103-06$ & $T X$ & $T X$ & 243 & 4.0 & $<0.2$ & 30.0 & 3.70 & & $1,2,3,4,8,9$ \\
\hline $93-107-07$ & $\mathrm{TX}$ & $T X$ & 245 & 4.0 & & & & & $1,2,3,4,8,9$ \\
\hline $93-107-08$ & $T X$ & $T X$ & 799 & 4.0 & $<0.5$ & & & & $1,3,4,5,6$ \\
\hline $93-126-03$ & $T X$ & $\mathrm{TX}$ & 376 & 4.0 & $<0.2$ & & & & $1,2,3,4,9$ \\
\hline $93-133-01$ & TX & $T X$ & 95 & 0.2 & $<0.5$ & & & & $1,5,7$ \\
\hline $93-195-01$ & $T X$ & TX,TY & 836 & 4.0 & $<0.2$ & & & & $5,6,9$ \\
\hline 93-195-01 & $T X$ & $T X$ & 744 & 4.0 & $<0.2$ & & & & 6,9 \\
\hline $93-211-03$ & TX & TX & 919 & 4.0 & $<0.2$ & & & & $5,6,9$ \\
\hline 93-364-01 & $\mathrm{TX}$ & $T X$ & 465 & 4.0 & $<0.5$ & & & & $1,2,3,4,9$ \\
\hline $94-152-02$ & $T X$ & TX,TY & 641 & 4.0 & $<0.5$ & 220.0 & $<0.24$ & & $5,6,7,9$ \\
\hline $94-206-03$ & $T X$ & $\mathrm{TX}$ & 292 & 4.0 & $<0.5$ & & & & $1,2,3,4,5,8,9$ \\
\hline
\end{tabular}




\section{TANK FARMS LLW}

93/94 HISTORICAL PIN FILES

\begin{tabular}{|c|c|c|c|c|c|c|c|c|c|}
\hline \multirow[t]{2}{*}{ PIN \# } & \multirow[t]{2}{*}{ Accum. Pt } & \multirow{2}{*}{$\begin{array}{l}\text { Point of } \\
\text { Origin }\end{array}$} & \multirow{2}{*}{$\begin{array}{c}\text { Weight } \\
(\mathrm{Kg})\end{array}$} & \multirow{2}{*}{$\frac{\text { Volume }}{\left(\mathrm{m}^{3}\right)}$} & \multirow{2}{*}{$\frac{6 \mathrm{pt}}{(\mathrm{mr} / \mathrm{hr})}$} & \multicolumn{2}{|c|}{ ASSAY } & \multirow{2}{*}{$\begin{array}{l}\text { SAMPLE } \\
\text { Tot. Act. } \\
\text { (pCi/g) }\end{array}$} & \multirow{2}{*}{$\begin{array}{l}\text { MAJOR CONTENTS } \\
\text { (see below) }\end{array}$} \\
\hline & & & & & & $\begin{array}{r}\text { Cs-137 } \\
\text { (p }\end{array}$ & $\begin{array}{l}\mathrm{C}_{0-60} \\
\text { g) }\end{array}$ & & \\
\hline 93-103-03 & $U$ & $U$ & 730 & 4.0 & $<0.5$ & & & & $1,2,3,4,5,6,9$ \\
\hline $93-103-04$ & $U$ & U & 263 & 4.0 & $<0.2$ & 4.1 & 0.38 & & $1,2,3,4$ \\
\hline $93-110-13$ & $U$ & $152-U \mathrm{DB}$ & 236 & 4.0 & & 0.86 & $<0.53$ & & $2,3,4,5,6,7$ \\
\hline $93-327-01$ & $U$ & $U$ & 269 & 4.0 & $<0.5$ & & & & $1,2,3,4,9$ \\
\hline $93-327-01$ & $U$ & $\mathrm{U}$ & 422 & 4.0 & $<0.5$ & & & & $1,2,3,4,5,6,9$ \\
\hline $94-206-02$ & $U$ & $\mathrm{U}$ & 301 & 4.0 & $<0.5$ & & & & $1,2,3,4,5,6,9$ \\
\hline $94-227-01$ & $U$ & $U$ & 346 & 4.0 & $<0.5$ & & & & $1,2,3,4,5,6,9$ \\
\hline
\end{tabular}




\section{ATTACHMENT A}

TANK FARMS LLW

93/94 HISTORICAL PIN FILES

\begin{tabular}{|c|c|c|c|c|c|c|c|c|c|}
\hline \multirow[t]{2}{*}{ PIN\# } & \multirow[t]{2}{*}{ Accum. Pt } & \multirow[t]{2}{*}{$\begin{array}{c}\text { Point of } \\
\text { Origin }\end{array}$} & \multirow{2}{*}{ Weight } & \multirow{2}{*}{$\begin{array}{l}\text { Volume } \\
\left(\mathrm{m}^{3}\right)\end{array}$} & \multirow{2}{*}{$6 \mathrm{pt}$} & \multicolumn{2}{|c|}{ ASSAY } & \multirow{2}{*}{$\begin{array}{l}\text { SAMPLE } \\
\text { Tot. Act. } \\
\text { (pci/g) }\end{array}$} & \multirow{2}{*}{$\begin{array}{c}\text { MAJOR CONTENTS } \\
\text { (see below) }\end{array}$} \\
\hline & & & & & & $\begin{array}{r}\mathrm{Cs}-137 \\
(\mathrm{p}\end{array}$ & $\begin{array}{l}\text { Co-60 } \\
\text { g) }\end{array}$ & & \\
\hline $93-153-01$ & 2713-WB & 2713-WB & 37.2 & 0.2 & $<0.5$ & 4.4 & $<2.4$ & & 1,9, OIL \\
\hline $94-053-01$ & 2713-W8 & 2713-WB & 903 & 4.0 & $<0.5$ & & & & $2,3,5,6,9$ \\
\hline 94-053-02 & 2713-WB & 2713-WB & 1988 & 4.0 & $<0.5$ & & & $<50$ & $3,4,5,6,9$ \\
\hline $94-053-03$ & 2713-WB & 2713-WB & 767 & 4.0 & $<0.5$ & & & & $1,3,4,5,6,9$ \\
\hline $94-053-04$ & $2713-W B$ & 2713-WB & 1721 & 4.0 & $<0.5$ & & & & $2,4,5,6,9$ \\
\hline $94-059-01$ & 2713-WB & 2713-WB & 28.6 & 0.2 & $<0.5$ & 1.5 & $<1.9$ & 178 & $2,5,9$, Oll. \\
\hline $94-059-02$ & 2713-WB & 2713-WB & 47.6 & 0.2 & $<0.5$ & 3.1 & 3.5 & $<50$ & 1,9, OlL \\
\hline $94-059-03$ & 2713-WB & 2713-WB & 162 & 0.2 & $<0.5$ & 5.4 & $<0.93$ & 990 & 1,9, OIL \\
\hline $94-067-04$ & 2713-WB & 2713-WB & 1975 & 4.0 & $<0.5$ & & & & 5,9 \\
\hline $94-069-03$ & 2713-WB & 2713-WB & 1542 & 4.0 & $<0.5$ & & & & 4,5 \\
\hline 94-074-01 & $2713-W B$ & 2713-WB & 1011 & 4.0 & $<0.5$ & $<0.32$ & $<0.26$ & & $3,5,6,9$ \\
\hline $94-087-03$ & 2713-WB & 2713-WB & 642 & 4.0 & $<0.5$ & $<0.45$ & $<0.33$ & & $3,4,5,9$ \\
\hline $94-115-01$ & 2713-WB & 2713-WB & 583 & 4.0 & $<0.5$ & 1.8 & $<0.4$ & $7.12 \mathrm{E}-03$ & $3,5,6$ \\
\hline $94-117-01$ & 2713-WB & $2713-W B$ & 297 & 4.0 & $<0.5$ & 2.8 & $<0.85$ & & 6,9 \\
\hline
\end{tabular}


HNF-SD-WM-ER-435, Rev. 2

ATTACHMENT B

B- 0 


\begin{tabular}{|c|c|c|c|c|c|c|c|c|c|c|c|c|c|c|c|c|c|c|c|}
\hline & & \multicolumn{18}{|c|}{ Radionuclide Data (pCi/g) } \\
\hline Location & $\begin{array}{c}\text { Sample } \\
\#\end{array}$ & Total Alpha & Total Beta & $k-40$ & Co-60 & Sr-90 & Cs-137 & Eu-152 & EU-154 & Eu-155 & Th-232 & Total U & U-235 & $\mathrm{U}-233$ & Np-237 & Pu-238 & $\begin{array}{l}\text { Pu-2391 } \\
\text { Pu-240 } \\
\end{array}$ & Pu-241 & Am-241 \\
\hline 241-AN & SA233 & $2.17 E+00$ & $1.72 E+01$ & $0.00 E+00$ & $1.13 E+00$ & $7.27 E-01$ & $4.09 E+00$ & $0.00 E+00$ & $1.49 E-01$ & $0.00 E+00$ & $2.27 \mathrm{E}-03$ & $4.94 \mathrm{E}-01$ & $4.00 E-02$ & $5.74 E-01$ & $0.00 E+00$ & $8.75 E-02$ & $2.00 E-01$ & $4.35 E+00$ & $1.87 E-01$ \\
\hline 241-AY & SA234 & $5.20 \mathrm{E}-01$ & 1.57E+01 & $0.00 E+\infty 0$ & $2.96 E-01$ & $1.15 E+\infty 0$ & $1.00 E+00$ & $0.00 E+00$ & $7.76 \mathrm{E}-02$ & $0.00 E+00$ & $1.59 \mathrm{E}-03$ & $1.42 E-01$ & $0.00 \mathrm{E}+00$ & $1.60 \mathrm{E}-01$ & $4.30 \mathrm{E}-02$ & $1.38 E-02$ & $2.34 E-01$ & $2.39 E+00$ & $1.09 E-01$ \\
\hline $241-B$ & SA235 & $3.70 E-01$ & 1.77E+01 & $0.00 E+00$ & $7.52 E+00$ & $1.14 E+00$ & $4.07 E+00$ & $0.00 E+00$ & $0.00 E+00$ & $0.00 E+00$ & $1.70 \mathrm{E}-03$ & $1.78 E-02$ & $0.00 E+00$ & $3.96 E-02$ & $0.00 E+00$ & $3.65 E-02$ & $1.06 E-01$ & $3.22 E+00$ & $1.07 E-01$ \\
\hline $241-\mathrm{BX} / \mathrm{BY}$ & SA236 & $0.00 \mathrm{E}+00$ & $9.38 E+00$ & $0.00 \mathrm{E}+00$ & 7.11E-01 & $5.86 E-01$ & $4.63 E+00$ & $0.00 E+00$ & $1.43 \mathrm{E}-01$ & $0.00 \mathrm{E}+00$ & $0.00 E+00$ & $4.00 E-02$ & $0.00 E+00$ & $4.45 E-02$ & $2.90 \mathrm{E}-02$ & $0.00 E+00$ & $1.35 E-02$ & $1.81 E+00$ & $9.72 \mathrm{E}-02$ \\
\hline $241-C$ & SA237 & $1.28 E+00$ & $3.05 E+01$ & $0.00 E+00$ & $1.33 E-01$ & $2.07 E+00$ & $7.65 E+00$ & $0.00 E+00$ & $0.00 E+00$ & $0.00 E+00$ & $5.93 \mathrm{E}-03$ & $0.00 E+00$ & $0.00 E+00$ & 1.64E-02 & $0.00 E+00$ & $3.69 E-02$ & $3.23 E-01$ & $5.25 E+00$ & $3.87 E-01$ \\
\hline $241-s / 5 x$ & SA238 & $0.00 E+00$ & $2.37 E+\infty 0$ & $0.00 E+00$ & $2.07 E-01$ & $0.00 \mathrm{E}+00$ & $1.66 E+00$ & $0.00 \mathrm{E}+00$ & $0.00 \mathrm{E}+00$ & $0.00 E+00$ & $9.43 E-04$ & $0.00 E+00$ & $0.00 E+00$ & $1.08 \mathrm{E}-02$ & $0.00 \varepsilon+00$ & $3.67 E-02$ & $4.04 E-02$ & $1.60 E+00$ & $0.00 E+\infty 0$ \\
\hline $241 .-T$ & SA239 & $0.00 E+\infty 0$ & $1.98 E+00$ & $0.00 E+00$ & $7.09 E-02$ & $0.00 E+00$ & $6.03 \mathrm{E}-01$ & $0.00 E+00$ & $0.00 E+00$ & $0.00 E+00$ & $4.60 E-04$ & $5.51 \mathrm{E}-02$ & $0.00 E+00$ & $7.27 \mathrm{E}-02$ & $2.50 \mathrm{E}-02$ & $0.00 E+00$ & $1.79 E-02$ & $0.00 E+00$ & $0.00 E+00$ \\
\hline $241-\mathrm{T} \times \pi \mathrm{TY}$ & SA240 & $0.00 E+00$ & $1.77 \mathrm{E}+00$ & $0.00 E+00$ & $1.82 E-01$ & $0.00 E+00$ & $4.58 \mathrm{E}-01$ & $0.00 E+00$ & $0.00 E+00$ & $0.00 \mathrm{E}+00$ & $2.01 \mathrm{E}-03$ & $0.00 E+00$ & $0.00 E+00$ & $1.39 \mathrm{E}-02$ & $0.00 E+00$ & $0.00 E+00$ & $0.00 E+00$ & $0.00 E+00$ & $2.34 \mathrm{E}-02$ \\
\hline $241-U$ & SA241 & 4. $10 \mathrm{E}-0.1$ & $1.07 E+01$ & $0.00 E+00$ & $9.95 \mathrm{E}-01$ & $5.82 E-01$ & $2.01 E+00$ & $0.00 E+00$ & $0.00 E+00$ & $0.00 E+00$ & $3.58 E-04$ & $0.00 E+00$ & $0.00 E+00$ & $3.89 \mathrm{E}-02$ & $0.00 E+00$ & $2.89 \Xi-02$ & $7.23 E-02$ & $1.27 E+00$ & $8.38 \mathrm{E}-02$ \\
\hline 241-SY & SA242 & $0.00 \varepsilon+\infty 0$ & $3.16 E+00$ & $0.00 E+00$ & $4.91 \mathrm{E}-01$ & $0.00 E+00$ & $2.91 E+00$ & $0.00 \mathrm{E}+00$ & $0.00 E+00$ & $0.00 E+00$ & $9.46 E-04$ & $2.02 \mathrm{E}-02$ & $0.00 E+00$ & $3.25 \mathrm{E}-02$ & $0.00 E+00$ & $8.67 E-03$ & $7.73 E-02$ & $1.08 E+01$ & $4.63 E-02$ \\
\hline $242-A$ & SA243 & $0.00 \mathrm{E}+00$ & $3.81 E+\infty 0$ & $0.00 E+00$ & $9.56 E-02$ & $3.34 E-01$ & $9.99 E-01$ & $0.00 E+00$ & $0.00 E+00$ & $0.00 E+00$ & $1.19 \mathrm{E}-03$ & $0.00 E+00$ & $0.00 E+00$ & $1.70 E-02$ & $0.00 E+00$ & $1.21 E-02$ & $1.58 E-02$ & $0.00 E+00$ & $2.05 \mathrm{E}-02$ \\
\hline 204AR & SA244 & $1.13 E+00$ & $2.52 \mathrm{E}+01$ & $9.08 E-01$ & $3.51 E+\infty 0$ & $7.80 E-01$ & $1.52 E+01$ & $4.85 \mathrm{E}-01$ & $8.45 \mathrm{E}-01$ & $2.76 \mathrm{E}-01$ & $1.09 E-03$ & $7.49 \mathrm{E}-02$ & $0.00 \mathrm{E}+00$ & $1.29 \mathrm{E}-01$ & $0.00 E+00$ & & & $0.00 E+00$ & $2.03 E-01$ \\
\hline $209-E$ & SA245 & $0.00 E+00$ & $8.34 E+00$ & $4.16 E-01$ & $9.14 \mathrm{E}-02$ & $5.45 E-01$ & $1.30 E+00$ & $0.00 E+C 0$ & $0.00 E+00$ & $0.00 E+00$ & $3.71 \mathrm{E}-04$ & $1.55 \mathrm{E}-02$ & $0.00 E+00$ & $1.30 \mathrm{E}-02$ & $0.00 E+00$ & $0.00 E+00$ & $0.00 E+00$ & $0.00 E+00$ & $0.00 E+00$ \\
\hline
\end{tabular}


Radionuclide Data (pCi/g)

\begin{tabular}{|c|c|c|c|c|c|c|c|c|c|c|c|c|c|c|c|c|c|}
\hline & & \\
\hline Lecation & Samplot & Anpa & Toral 1 eta & 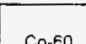 & 5.00 & cs 137 & $=15$ & & The? & Toth & 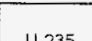 & 14327 & הרי & 8.238 & Pu-239: & Ounat: & 41 \\
\hline $244 \mathrm{~A}$ & SA247 & $1.61 E+00$ & $1.52 E+01$ & $1.01 E+\infty$ & $4.14 \mathrm{E}+00$ & $264 E+00$ & $764 E-01$ & $0,00 E+00$ & $200 E-03$ & $203 E-01$ & $792 \mathrm{E}-03$ & $195 \mathrm{E}-01$ & $0.00 E+00$ & $1.34 E-01$ & $497 \mathrm{E}-01$ & $400 E+00$ & $391 \mathrm{E}-01$ \\
\hline $241-A Y$ & 248 & $5.70 \mathrm{E}-01$ & $6.71 E+\infty$ & $4.02 \mathrm{E}-01$ & $2.01 E+00$ & $1.60 E+100$ & $0.00 E+\infty$ & $0.00 E+\infty$ & $3.42 \mathrm{E}-03$ & $7.71 \mathrm{E}-02$ & $0.00 E+00$ & $7.71 \mathrm{E}-02$ & $3.20 E-02$ & $1.46 E-02$ & $1.26 \mathrm{E}-01$ & & \\
\hline $241-S Y$ & & $90 \mathrm{E}-01$ & $3 E+01$ & $1.03 E-01$ & $5.70 \mathrm{E}-01$ & $4.81 E+00$ & $0.00 E+00$ & $0.00 E+00$ & $2.26 E-03$ & $3.01 E-02$ & $0.00 \varepsilon+00$ & $3.01 E-02$ & $0.00 E+00$ & $0.00 E+00$ & $5.60 \mathrm{E}-02$ & $0.00 E+00$ & $3.35 \mathrm{E}-02$ \\
\hline & & $5.30 \mathrm{E}-01$ & $1.87 E+01$ & $6.42 \mathrm{E}+00$ & & & & & & & $0.00 E+00$ & & & $2.31 \mathrm{E}-02$ & $1.48 E-01$ & & \\
\hline $241-\mathrm{AW}$ & & $1.00 E+00$ & $2.06 E+01$ & $6.75 \mathrm{E}-01$ & $7.39 E+00$ & $3.28 E+00$ & $0.00 E+00$ & $0.00 E+00$ & $1.69 E-03$ & $2.59 E-01$ & $1.51 \mathrm{E}-02$ & $2.44 E-01$ & $3.00 E-02$ & $2.21 E-02$ & $1,20 \mathrm{E} \cdot 01$ & $0.00 E+00$ & $9.30 E-02$ \\
\hline $242-A$ & 2252 & $7.20 E-01$ & $1.50 E+01$ & $1.46 E+00$ & $3.44 E+00$ & $4.39 E+00$ & $8.62 \mathrm{E}-01$ & $0.00 E+00$ & $30 \mathrm{E}-03$ & $15 \mathrm{E}-02$ & $0.00 E+D 0$ & & $0.00 E+00$ & $0 . \angle U E=-U Z$ & & $2.30 E+50$ & \\
\hline 241 & & $3.90 \mathrm{E}-01$ & $105 E+01$ & $1.88 \mathrm{E}-01$ & $3.19 E+00$ & $2.30 E+00$ & $0.00 E+00$ & $0.00 E+00$ & $1.98 E-03$ & $4.40 E-02$ & $0.00 E+\infty 0$ & $4.40 E-02$ & 1.90E-01 & $1.27 \mathrm{E}-02$ & $6.28 \mathrm{E}-02$ & $0.00 E+\infty 0$ & $7.96 \mathrm{E}-02$ \\
\hline 241-BX/BY & 254 & $2.20 \mathrm{E}-01$ & $6.74 E+00$ & $4.57 E+00$ & $2.38 \mathrm{E}+00$ & $2.08 \mathrm{E}+00$ & $0.00 E+00$ & $0.00 \mathrm{E}+00$ & $1.17 E-03$ & $1.43 \mathrm{E}-02$ & $0.00 E+00$ & $43 E-02$ & $3.40 \mathrm{E}-02$ & $0.00 E+00$ & $3.44 E-02$ & $0.00 E+00$ & $3.57 \mathrm{E}-02$ \\
\hline & & $3.20 E-01$ & & $1.75 \mathrm{E}-01$ & $1.13 E+00$ & $1.02 E+00$ & $0.00 \bar{E}+\infty$ & $0.00 E+00$ & $2.58 E-03$ & $7.11 \mathrm{E}-02$ & $3.40 \mathrm{E}-03$ & $6.77 \mathrm{E}-02$ & $0.00 E+00$ & $0.00 \overline{E+00}$ & $2.29 E \cdot 02$ & $0.00 E+00$ & $4.08 E-02$ \\
\hline $209-E$ & SA256 & $2.89 E+00$ & $3.26 \mathrm{E}+01$ & $2.10 E+01$ & $5.93 E+00$ & $8.54 E+00$ & $6.24 \mathrm{E}-01$ & $0.00 E+00$ & $8.64 \varepsilon-04$ & $8.56 \mathrm{E}-01$ & $4.23 \mathrm{E}-02$ & & $3.70 \mathrm{E}-02$ & $3.76 \mathrm{E}-02$ & $87 E-01$ & $2.10 E+00$ & $2.71 \mathrm{E}-01$ \\
\hline & & $E+00$ & & $2 E+00$ & $3.21 E+00$ & $2.14 E+\infty 0$ & $0.00 E+00$ & $0.00 E+00$ & $1.35 \mathrm{E}-03$ & $2.08 E-02$ & $0.00 E+00$ & $2.08 E-02$ & $0.00 E+00$ & 8.47E-02 & $98 E+C 0$ & $5.70 E+20$ & $5.60 \mathrm{E}-01$ \\
\hline & 2258 & $4.30 E-01$ & $1.35 \mathrm{E}+01$ & $1.36 \mathrm{E} \cdot 01$ & $4.56 E+00$ & $1.75 E+\infty 0$ & $0.00 E+00$ & $0.00 E+00$ & $1.17 \mathrm{E}-03$ & $5.68 \mathrm{E}-02$ & $0.00 \mathrm{E}+00$ & $5.68 \mathrm{E}-02$ & $0.00 E+00$ & $1.08 \mathrm{E}-02$ & $35 \mathrm{E}-02$ & $0.00 E+00$ & 7.14E-02 \\
\hline & & & & & $8 E+00$ & $3.45 E+00$ & $0.00 E+00$ & $0.00 E+00$ & & 1.00 & 4.61E-03 & $9.54 \mathrm{E}-02$ & $0.00 \mathrm{E}+00$ & $3.34 \mathrm{E}-02$ & $3.70 E-01$ & $2.20 E++0$ & $2.02 \mathrm{E}-01$ \\
\hline $241-\mathrm{T} X \mathrm{TTY}$ & SA261 & $0.00 E+00$ & $1.92 E+00$ & $0.00 E+00$ & $2.90 \mathrm{E}-01$ & $6.88 \mathrm{E}-01$ & $0.00 \mathrm{E}+00$ & $0.00 E+00$ & $9.73 \mathrm{E}-04$ & $8.15 E-03$ & $0.00 E+00$ & $E-03$ & & & $2 E-03$ & & \\
\hline 241 & $\mathrm{~s}$ & $2.60 \mathrm{E}-01$ & & & & $20 \mathrm{E}-01$ & +00 & $0.00 E+00$ & & & $0.00 E+00$ & $1.20 \mathrm{E}-02$ & $0.00 E+00$ & $8.90 E-03$ & $75 E-02$ & $.00 E+00$ & \\
\hline $241-U$ & SA263 & $9.90 E-01$ & $1.55 \mathrm{E}+00$ & $7.75 E-01$ & $1.91 E+\infty 0$ & $9.23 E+00$ & $0.00 \mathrm{E}+00$ & $3.00 E-04$ & $1.88 E-03$ & $2.87 \mathrm{E}-01$ & $1.47 E-02$ & $2.72 \mathrm{E}-01$ & 1.70E-02 & 1. 66 EE-02 & $1.21 \mathrm{E}-01$ & $0.00 E+00$ & \begin{tabular}{|l|l|}
$6.41 E-02$ \\
\end{tabular} \\
\hline
\end{tabular}


HNF-SD-WM-ER-435, Rev. 2

ATTACHMENT C 


\section{Attachment C \\ Table 1. Average Radionuclide Concentration - 1/30/96 + 3/13/96}

\begin{tabular}{|c|c|c|}
\hline Nuclide & & $\begin{array}{c}\text { Average } \\
\text { (pCi/g) }\end{array}$ \\
\hline Total Alpha & & $6.84 \mathrm{E}-01$ \\
\hline Total Beta & & $1.18 E+01$ \\
\hline $\mathrm{K}-40$ & & $4.57 \mathrm{E}-02$ \\
\hline Co-60 & & $2.07 E+00$ \\
\hline Sr-90 & & $1.97 \mathrm{E}+00$ \\
\hline Cs -137 & & $3.46 E+00$ \\
\hline Eu-152 & & $1.67 \mathrm{E}-02$ \\
\hline Eu-154 & & $1.30 \mathrm{E}-01$ \\
\hline Eu-155 & & $9.52 E-03$ \\
\hline $\operatorname{Re}-187$ & & $1.03 E-05$ \\
\hline Th-232 & & $1.57 \mathrm{E}-03$ \\
\hline Total-U & note1 & $2.20 \mathrm{E}-01$ \\
\hline U-234 & note1 & $1.05 E-01$ \\
\hline U-235 & note 1 & $4.56 \mathrm{E}-03$ \\
\hline $\mathrm{U}-238$ & & $1.10 \mathrm{E}-01$ \\
\hline $\mathrm{Np}-237$ & & $1.59 \mathrm{E}-02$ \\
\hline Pu-238 & & $2.96 \mathrm{E}-02$ \\
\hline Pu-239/240 & & $1.90 \mathrm{E}-01$ \\
\hline Pu-239 & note2 & $1.54 \mathrm{E}-01$ \\
\hline $\mathrm{Pu}-240$ & note? & $3.60 \mathrm{E}-02$ \\
\hline Pu-241 & & $1.68 \mathrm{E}+00$ \\
\hline $\mathrm{Am}-241$ & & $1.24 \mathrm{E}-01$ \\
\hline
\end{tabular}

Note 1: The U-234 and U-235 isotopic Total-U data are based upon the original U-238 pClig sampling result and the U-isotopic distribution determined from the average 200 Area environmental data presented in Table E-2 of the WHC.EP.0573-2 report.

Note 2: The PU-239 and PU.240 resuits are based upon the original PU. $239 / 240$ result assuming that the PU-240 content is $6 \%$ by weight. 


\section{Attachment C}

Table 2. Average Radionuclide Ratios $-1 / 30 / 96+3 / 13 / 96$

\begin{tabular}{|c|c|}
\hline Nuclide & $\begin{array}{l}\text { Avg. Nuclide/ } \\
\text { Cs-137 Ratio }\end{array}$ \\
\hline Total Alpha & $1.98 \mathrm{E}-01$ \\
\hline Total Beta & $3.40 E+00$ \\
\hline $\mathrm{K}-40$ & $1.32 \mathrm{E}-02$ \\
\hline Co-60 & 5.99E-01 \\
\hline Sr-90 & $5.69 E-01$ \\
\hline Cs-137 & $1.00 E+00$ \\
\hline Eu-152 & 4.84E-03 \\
\hline Eu-154 & $3.76 E-02$ \\
\hline Eu-155 & $2.75 E-03$ \\
\hline Re-187 & $2.99 E-06$ \\
\hline Th-232 & $4.56 \mathrm{E}-04$ \\
\hline Total-U & $6.36 E-02$ \\
\hline $\mathrm{U}-234$ & $3.03 E-02$ \\
\hline U-235 & $1.32 E-03$ \\
\hline U-238 & $3.18 E-02$ \\
\hline $\mathrm{Np}-237$ & $4.59 \mathrm{E}-03$ \\
\hline Pu-238 & $8.56 \mathrm{E}-03$ \\
\hline $\mathrm{Pu}-239 / 240$ & $5.51 \mathrm{E}-02$ \\
\hline Pu-239 & $4.45 \mathrm{E}-02$ \\
\hline Pu-240 & $1.04 \mathrm{E}-02$ \\
\hline Pu-241 & $4.85 \mathrm{E}-01$ \\
\hline Am-241 & $3.60 \mathrm{E}-02$ \\
\hline
\end{tabular}


HNF-SD-WM-ER-435, Rev. 2

ATTACHMENT D 


\section{Attachment D}

Table 1. Average Sea-Land Container Data

\begin{tabular}{|c|c|c|c|}
\hline Shipment \# & $\begin{array}{c}\text { Waste } \\
\text { Volume }\left(\mathrm{m}^{3}\right)\end{array}$ & $\begin{array}{c}\text { Waste } \\
\text { Weight } \\
\text { (grams) }\end{array}$ & $\begin{array}{c}\text { Compaction } \\
\text { Factor }\end{array}$ \\
\hline RL-21 & 33.13 & $3.44 \mathrm{E}+06$ & 7.53 \\
RL-23 & 33.13 & $2.64 \mathrm{E}+06$ & 7.91 \\
RL-25 & 33.13 & $2.44 \mathrm{E}+06$ & 10.30 \\
RL-29 & 33.13 & $2.20 \mathrm{E}+06$ & 10.26 \\
RL-30 & 33.13 & $2.98 E+06$ & 8.55 \\
RL-32 & 33.13 & $2.77 E+06$ & 8.64 \\
RL-33 & 33.13 & $3.43 E+06$ & 7.40 \\
RL-34 & 33.13 & $3.16 E+06$ & 9.24 \\
RL-37 & 33.13 & $5.15 E+06$ & 10.16 \\
RL-38 & 33.13 & $3.14 E+06$ & 9.33 \\
RL-40 & 33.13 & $2.77 E+06$ & 8.48 \\
RL-44 & 33.13 & $3.43 E+06$ & 8.16 \\
RL-45 & 33.13 & $4.05 E+06$ & 7.20 \\
\hline Average & 33.13 & $3.20 E+06$ & 8.70 \\
\hline
\end{tabular}




\section{Attachment D \\ Table 2. Average Assay Nuclide Results}

\begin{tabular}{|l|c|c|}
\hline Nuclide & $\begin{array}{c}\text { @1/1/97 } \\
\text { Average results } \\
\text { (pci/g-pCi/g @ 95\% C.1. }\end{array}$ & $\begin{array}{c}\text { Nuclide/Cs-137 } \\
\text { Ratio }\end{array}$ \\
\hline Co-60 & $8.86 \mathrm{E}-1+/-6.57 \mathrm{E}-1$ & $4.36 \mathrm{E}-03$ \\
\hline $\mathrm{CS}-137$ & $2.03 \mathrm{E}+2+/-1.39 \mathrm{E}+2$ & $1.00 \mathrm{E}+00$ \\
\hline $\mathrm{Eu}-152$ & $6.27 \mathrm{E}-1+/-7.45 \mathrm{E}-1$ & $3.09 \mathrm{E}-03$ \\
\hline $\mathrm{Eu}-154$ & $9.54 \mathrm{E}-1+/-6.27 \mathrm{E}-1$ & $4.70 \mathrm{E}-03$ \\
\hline
\end{tabular}


HNF-SD-WM-ER-435, Rev. 2

\section{ATTACHMENT E}




\section{Attachment $\mathrm{E}$}

\section{Table 1. Radionuclide Concentrations Based Upon Concentration Method}

$\begin{array}{lcc}\text { Average Sea-Land net weight } & & 3.20 \mathrm{E}+06 \text { grams } \\ \text { Average Sea-Land volume } & = & 33.13 \mathrm{~m}^{3} \\ \text { Average compaction factor } & = & 8.70\end{array}$

\begin{tabular}{|c|c|c|c|c|c|c|c|c|c|}
\hline \multirow[b]{2}{*}{ Nuclide } & \multicolumn{2}{|c|}{ Container $\mathrm{Ci} / \mathrm{m}^{3}$} & \multicolumn{3}{|c|}{ Category / Comparison } & \multicolumn{3}{|c|}{ Mobile Nuclide Comparison } & \multirow[b]{2}{*}{$\begin{array}{c}\text { Container } \\
\text { TRU } \\
\text { (nCi/g) }\end{array}$} \\
\hline & $\begin{array}{c}\text { Without } \\
\text { compaction }\end{array}$ & $\begin{array}{c}\text { With } \\
\text { compaction }\end{array}$ & $\begin{array}{l}\text { Cat. I Limit } \\
\left(\mathrm{Ci} / \mathrm{m}^{3}\right)\end{array}$ & $\begin{array}{c}\text { Fraction } \\
\text { without } \\
\text { compaction }\end{array}$ & $\begin{array}{l}\text { Fraction with } \\
\text { compaction }\end{array}$ & $\begin{array}{l}\text { Reporting } \\
\text { Limit } \\
\left(\mathrm{Ci} / \mathrm{m}^{3}\right)\end{array}$ & $\begin{array}{c}\text { Fraction } \\
\text { without } \\
\text { compaction }\end{array}$ & $\begin{array}{c}\text { Fraction with } \\
\text { compaction }\end{array}$ & \\
\hline$K-40$ & $4.41 E-09$ & $3.84 \mathrm{E}-08$ & $1.80 E-03$ & $245 \mathrm{E}-06$ & $2.13 E-05$ & $N / A$ & $N / A$ & N/A & N/A \\
\hline 60.60 & $2.00 E-07$ & $1.74 E-06$ & $7.50 E+01$ & $2.66 \mathrm{E}-09$ & $2.32 E-08$ & N/A & N/A & $\mathrm{N} / \mathrm{A}$ & N/A \\
\hline $5 r-90$ & $1.90 \mathrm{E}-07$ & $1.65 \mathrm{E}-06$ & $1.60 \mathrm{E}-02$ & $1.19 E-05$ & $1.03 E-04$ & $\mathrm{~N} / \mathrm{A}$ & N/A & N/A & $\bar{N} / A$ \\
\hline Cs-137. & $3.34 \mathrm{E}-07$ & $2.90 \mathrm{E}-06$ & $5.50 \mathrm{E}-03$ & $6.07 E-05$ & $5.28 \mathrm{E}-04$ & N/A & N/A & $\mathrm{N} / \mathrm{A}$ & $N / A$ \\
\hline$E u-152$ & $1.62 \mathrm{E}-09$ & $1.41 E-08$ & 4.80E-02 & 3.37E-08 & $2.93 E-07$ & N/A & N/A & $\mathrm{N} / \mathrm{A}$ & N/A \\
\hline Eu-154 & $1.26 E-08$ & 1.09E-07 & $7.50 E-01$ & $1.67 \mathrm{E}-08$ & $1.46 \mathrm{E}-07$ & N/A & N/A & $N / A$ & $\mathrm{~N} / \mathrm{A}$ \\
\hline $\operatorname{Re}-187$ & $9.99 E-13$ & $8.69 E-12$ & $3.60 E+01$ & $2.78 \mathrm{E}-14$ & $2.41 E-13$ & 3.30E-02 & 3.03E-11 & $2.63 E-10$ & $N / A$ \\
\hline$T h-232$ & $1.52 \mathrm{E}-10$ & 1.32E-09 & 1.10E-04 & 1.38E-06 & $1,20 \mathrm{E}-05$ & N/A & N/A & N/A & N/A \\
\hline Total-U & $2.12 E-08$ & 1.85E-07 & N/A & N/A & $N / A$ & $1.40 \mathrm{E}-05$ & $1.51 \mathrm{E}-03$ & $1.32 E-02$ & N/A \\
\hline U-234 & $1.01 \mathrm{E}-08$ & $8.79 \mathrm{E}-08$ & $280 E-03$ & $3.61 E-06$ & $3.14 \mathrm{E}-05$ & N/A & N/A & N/A & $N / A$ \\
\hline $\mathrm{U}-235$ & $4.40 E-10$ & $3.83 E-09$ & $2.80 E-03$ & $1.57 \mathrm{E}-07$ & 1.37E-06 & N/A & N/A & N/A & $N / A$ \\
\hline $\mathrm{U}-238$ & $1.06 \mathrm{E}-08$ & $9.25 E-08$ & $5.70 E-03$ & 1.87E-06 & 1.62E-05 & N/A & N/A & N/A & $\mathrm{N} / \mathrm{A}$ \\
\hline Np-237 & $1.53 \mathrm{E}=09$ & $1.33 \mathrm{E}-08$ & $6.80 E-04$ & $2.25 \mathrm{E}-06$ & $1.96 \mathrm{E}-05$ & $1.10 \mathrm{E}-05$ & 1.39E-04 & $1.21 E-03$ & $1.59 \mathrm{E}-05$ \\
\hline Pu-238 & 2.66E-09 & $2.43 \mathrm{E}-08$ & $4.70 E-03$ & $6.08 \mathrm{E}-07$ & $5.29 \mathrm{E}-0.5$ & $N / A$ & $N / A$ & N/A & $2.96 E-05$ \\
\hline $\mathrm{Pu}-239 / 240$ & 1.84E-08 & $1.60 E-07$ & $1.90 \mathrm{E}-03$ & $9.68 \mathrm{E}-06$ & $8.42 \mathrm{E}-05$ & N/A & N/A & N/A & $1.90 E-04$ \\
\hline$P \cup-241$ & $1.62 \mathrm{E}-07$ & $1.41 \mathrm{E}-06$ & 6.10E-02 & 2.65E-06 & $2.31 \mathrm{E}-05$ & N/A & N/A & N/A & $1.68 E-03$ \\
\hline Am-241 & 1.20E-08 & 1.04E-07 & $2.10 E-03$ & 5.71E-06 & 4.97E-05 & N/A & N/A & N/A & 1.24E-04 \\
\hline Total & $9.505-07$ & $853 E-06$ & $N / A$ & $9.94 E-05$ & $8.65 E-04$ & $\mathrm{~N} / \mathrm{A}$ & $1.65 E-03$ & $1.44 \mathrm{E}-02$ & $2.04 E-03$ \\
\hline
\end{tabular}




\section{Attachment $\mathrm{E}$ \\ Table 2. Radionuclide Concentration Based upon Cs-137 Ratio Method}

$\begin{array}{lc}\text { Average Cs }-137 \mathrm{pCi} / \mathrm{g} & 2.03 E+02 \\ \text { Average Sea-Land net wieight }= & 3.20 E+0.0 \mathrm{grams} \\ \text { Average Sea-Land volume }= & 33.13 \mathrm{~m}^{3} \\ \text { Average compaction factor }= & 8.70\end{array}$

\begin{tabular}{|c|c|c|c|c|c|c|c|c|c|}
\hline \multirow[b]{2}{*}{ Nuclide } & \multicolumn{2}{|c|}{ Container $\mathrm{Cl} / \mathrm{m}^{3}$} & \multicolumn{3}{|c|}{ Category / Comparison } & \multicolumn{3}{|c|}{ Mobile Nuclide Comparison } & \multirow{2}{*}{$\begin{array}{c}\text { Container } \\
\text { with } \\
\text { Compaction } \\
\text { TRU (ncilg) }\end{array}$} \\
\hline & $\begin{array}{c}\text { Without } \\
\text { compaction }\end{array}$ & $\begin{array}{c}\text { With } \\
\text { compaction }\end{array}$ & $\begin{array}{c}\text { Cat. I Limit } \\
\left(\mathrm{Ci} / \mathrm{m}^{3}\right)\end{array}$ & $\begin{array}{c}\text { Fraction } \\
\text { without } \\
\text { compaction }\end{array}$ & $\begin{array}{c}\begin{array}{c}\text { Fraction } \\
\text { with } \\
\text { compaction }\end{array} \\
\end{array}$ & $\begin{array}{c}\text { Reporting } \\
\text { Limit } \\
\left(\mathrm{Ci} / \mathrm{m}^{3}\right)\end{array}$ & $\begin{array}{c}\text { Fraction } \\
\text { without } \\
\text { compaction }\end{array}$ & $\begin{array}{c}\text { Fraction } \\
\text { with } \\
\text { compaction }\end{array}$ & \\
\hline $\mathrm{K}-40$ & $2.59 \mathrm{E}-07$ & $2.25 \mathrm{E}-06$ & $1.80 \mathrm{E}-03$ & $1.44 \mathrm{E}-04$ & $1.25 E-03$ & $\mathrm{~N} / \mathrm{A}$ & $N / A$ & N/A & $N / A$ \\
\hline $00-60$ & 1.17E-05 & $1.02 E-04$ & $7.50 E+01$ & $1.56 \mathrm{E}-07$ & $1.36 \mathrm{E}-06$ & $\mathrm{~N} / \mathrm{A}$ & N/A & N/A & N/A \\
\hline$S_{i-90}$ & 1.12E-05 & $9.74 E-05$ & $1.60 \mathrm{E}-02$ & 7.00E-04 & $6.09 E-03$ & N/A & N/A & $\mathrm{N} / \mathrm{A}$ & N/A \\
\hline Cs-137 & $1.95 \mathrm{E}-05$ & 1.71E-04 & $5.50 \mathrm{E}-03$ & $3.56 E-03$ & 3.11E-02 & N/A & N/A & N/A & N/A \\
\hline Eu-152 & $9.49 \mathrm{E}-08$ & $8.26 \mathrm{E}-07$ & 4.80E-02 & 1.98E-06 & $1.72 E-05$ & $\mathrm{~N} / \mathrm{A}$ & N/A & N/A & N/A \\
\hline EU-154 & $7.38 \mathrm{E}-07$ & $6.42 \mathrm{E}-06$ & $7.50 \mathrm{E}-01$ & $9.84 E-07$ & $8.56 \mathrm{E}-06$ & $\mathrm{~N} / \mathrm{A}$ & N/A & N/A & $\mathrm{N} / \mathrm{A}$ \\
\hline Re-187 & $5.86 E-11$ & $5.10 E-10$ & $3.60 E+01$ & 1.63E-12 & $1.42 E-11$ & $3.30 E-02$ & $1.78 \mathrm{E}-09$ & $1.55 E-08$ & $\mathrm{~N} / \mathrm{A}$ \\
\hline Tn-232 & $8.93 E-09$ & $7.77 \mathrm{E}-08$ & 1.10E-04 & $8.12 E-05$ & 7.06E-04 & $N / A$ & $N / A$ & $N / A$ & $N / A$ \\
\hline Tota! U & 1.25E-06 & $1.09 E-05$ & $\mathrm{~N} / \mathrm{A}$ & $N / A$ & N/A & $1.40 E-05$ & $8.93 \mathrm{E}-02$ & $7.79 E-01$ & N/A \\
\hline U-234 & $5.94 E-07$ & 5.17E-06 & $2.80 E-03$ & 2.12E-04 & $1.85 E-03$ & $N / A$ & $N / A$ & N/A & N/A \\
\hline $4-235$ & $2.59 E-08$ & $2.25 \mathrm{E}-07$ & $2.80 \mathrm{E}-03$ & $9.25 \mathrm{E}-06$ & $8.04 \mathrm{E}-05$ & $N / A$ & $\mathrm{~N} / \mathrm{A}$ & $N / A$ & $\mathrm{~N} / \mathrm{A}$ \\
\hline U-238 & $624 \mathrm{E}-07$ & $5.43 E-06$ & $5.70 E-03$ & $1.09 E-04$ & $9.53 \mathrm{E}-04$ & $\mathrm{~N} / \mathrm{A}$ & $\mathrm{N} / \mathrm{A}$ & N/A & $N / A$ \\
\hline $\mathrm{Np}-237$ & $9.01 \mathrm{E}-08$ & $7.84 \mathrm{E}-07$ & $6.80 E-04$ & 1.33E-04 & 1.15E-03 & $1.10 E-05$ & 8.19E-03 & 7.13E-02 & 1.72E-02 \\
\hline Pu-238 & $1.68 \mathrm{E}-07$ & $1.46 E-06$ & $470 \mathrm{E}-03$ & $3.57 \mathrm{E}-05$ & $3.11 E-04$ & $N / A$ & N/A & $N / A$ & $128 \mathrm{E}-02$ \\
\hline $\mathrm{Pu}-239 / 240$ & $1.08 E-00$ & $9.40 E-06$ & $1.90 \bar{E}-03$ & $5.68 E-04$ & $4.95 E-03$ & N/A & N/A & $\mathrm{N} / \mathrm{A}$ & 8.24E-02 \\
\hline$P u-241$ & $9.52 E-06$ & $8.28 E-05$ & 6.10E-02 & $1.56 \mathrm{E}-04$ & 1.36E-03 & N/A & N/A & N/A & $7.26 E-01$ \\
\hline$A m-241$ & $7.05 \mathrm{E}-07$ & $6.13 E-06$ & $2.10 E-03$ & 3.30E-04 & $2.92 \mathrm{E}-03$ & N/A & N/A & $N / A$ & $5.38 \mathrm{E}-02$ \\
\hline Tota! & $5.77 \mathrm{E}-05$ & $5.02 E-04$ & $N / A$ & $6.055-03$ & $5.27 \mathrm{E}-02$ & N/A & $9.75 E-02$ & $8.50 E-01$ & 8.92E-01 \\
\hline
\end{tabular}




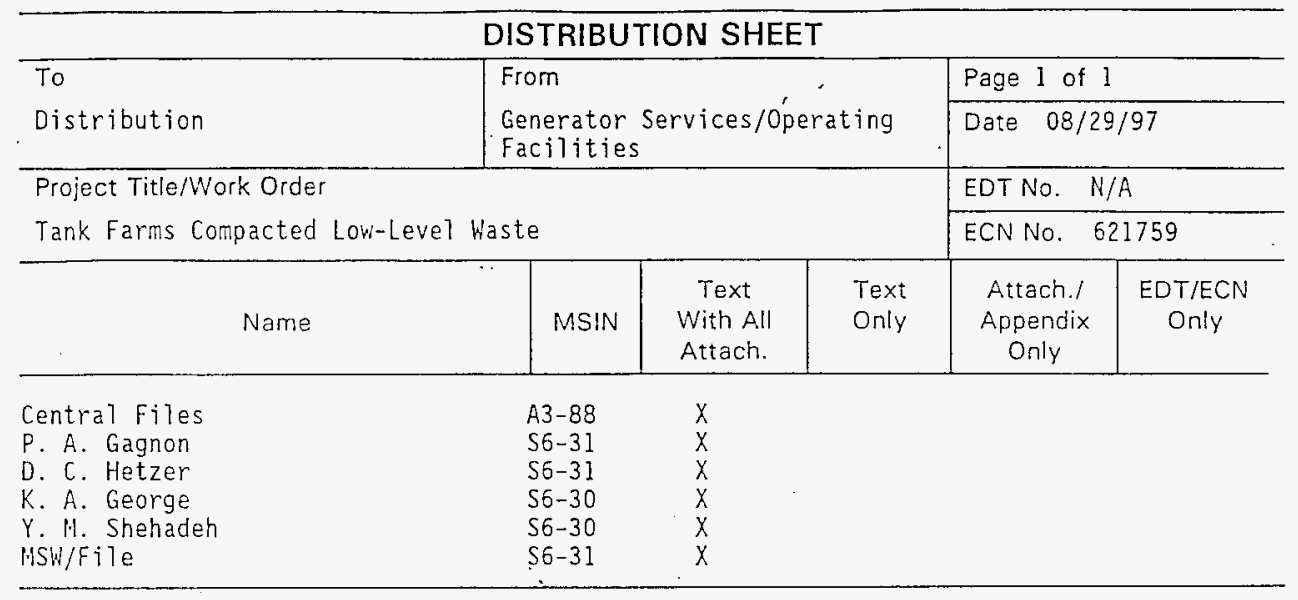

